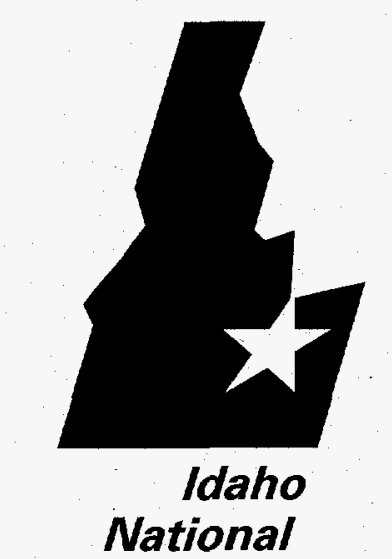

Engineering Laboratory
INEEL/EXT-97-00832

August 1997

Demonstration of a SREX Flowsheet for the Partitioning of Strontium and Lead from Actual ICPP SodiumBearing Waste
J. D. Law
D. J. Wood
L. G. Olson
T. A. Todd 


\section{DISCLAIMER}

This report was prepared as an account of work sponsored by an agency of the United States Government. Neither the United States Government nor any agency thereof, nor any of their employees, makes any warranty, express or implied, or assumes any legal liability or responsibility for the accuracy, completeness, or usefulness of any information, apparatus, product or process disclosed, or represents that its use would not infringe privately owned rights. References herein to any specific commercial product, process, or service by trade name, trademark, manufacturer, or otherwise, does not necessarily constitute or imply its endorsement, recommendation, or favoring by the United States Government or any agency thereof. The views and opinions of authors expressed herein do not necessarily state or reflect those of the United States Government or any agency thereof. 
INEEL/EXT-97-00832

\title{
Demonstration of a SREX Flowsheet for the Partitioning of Strontium and Lead from Actual ICPP Sodium-Bearing Waste
}

\author{
J. D. Law \\ D. J. Wood \\ L. G. Olson \\ T. A. Todd \\ Published August 1997 \\ Idaho National Engineering and Environmental Laboratory \\ High Level Waste Program \\ Lockheed Martin Idaho Technologies Company \\ Idaho Falls, Idaho 83415
}

Prepared for the

U.S. Department of Energy

Assistant Secretary for

Environmental Management

Under DOE Idaho Operations Office

Contract DE-AC07-94ID13223

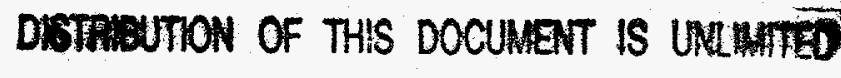




\section{DISCLAIMER}

Portions of this document may be illegible electronic image products. Images are produced from the best available original document. 


\section{ABSTRACT}

Laboratory experimentation has indicated that the SREX process is effective for partitioning ${ }^{90} \mathrm{Sr}$ and $\mathrm{Pb}$ from acidic radioactive waste solutions located at the Idaho Chemical Processing Plant. Previous countercurrent flowsheet testing of the SREX process with simulated waste resulted in $99.98 \%$ removal of $\mathrm{Sr}$ and $99.9 \%$ removal of $\mathrm{Pb}$. Based on the results of these studies, a demonstration of the SREX flowsheet was performed. The demonstration consisted of 1) countercurrent flowsheet testing of the SREX process using simulated sodium-bearing waste spiked with ${ }^{85} \mathrm{Sr}$ and 2) countercurrent flowsheet testing of the SREX process using actual waste from tank WM-183. All testing was performed using 24 stages of $2-\mathrm{cm}$ diameter centrifugal contactors which are installed in the Remote Analytical Laboratory hot cell. The flowsheet tested consisted of an extraction section $\left(0.15 M 4^{\prime}, 4^{\prime}(5)\right.$-di-(tertbutyldicyclohexo)-18-crown-6 and 1.5 MTBP in Isopar-L ${ }^{\circledR}$ ), a $2.0 M \mathrm{HNO}_{3}$ scrub section to remove extracted $\mathrm{K}$ from the SREX solvent, a $0.05 M \mathrm{HNO}_{3}$ strip section for the removal of $\mathrm{Sr}$ from the SREX solvent, a $0.1 \mathrm{M}$ ammonium citrate strip section for the removal of $\mathrm{Pb}$ from the SREX solvent, and a $3.0 \mathrm{M}$ $\mathrm{HNO}_{3}$ equilibration section. The behavior of ${ }^{90} \mathrm{Sr}, \mathrm{Pb}, \mathrm{Na}, \mathrm{K}, \mathrm{Hg}, \mathrm{H}^{+}$, the actinides, and numerous other non-radioactive elements was evaluated. The described flowsheet successfully extracted and selectively stripped $\mathrm{Sr}$ and $\mathrm{Pb}$ from the SBW simulant and the actual tank waste. For the testing with actual tank waste (WM-183), removal efficiencies of $99.995 \%$ and $>94 \%$ were obtained for ${ }^{90} \mathrm{Sr}$ and $\mathrm{Pb}$, respectively. With this removal efficiency for ${ }^{90} \mathrm{Sr}$, the activity of ${ }^{90} \mathrm{Sr}$ was reduced to $0.0089 \mathrm{Ci} / \mathrm{m}^{3}$ which is below the NRC Class A LLW limit of $0.04 \mathrm{Ci} / \mathrm{m}^{3}$ for ${ }^{90} \mathrm{Sr}$. Essentially all of the ${ }^{90} \mathrm{Sr}(99.99 \%)$ and $<6 \%$ of the $\mathrm{Pb}$ exited with the $0.05 \mathrm{M}$ nitric acid strip product; whereas, $0.007 \%$ of the ${ }^{90} \mathrm{Sr}$ and $93 \%$ of the $\mathrm{Pb}$ exited with the $0.1 \mathrm{M}$ ammonium citrate strip product. Also, $94 \%$ of the total alpha, $1.9 \%$ of the ${ }^{241} \mathrm{Am}, 99.94 \%$ of the ${ }^{238} \mathrm{Pu}, 99.97 \%$ of the ${ }^{239} \mathrm{Pu}, 37.2 \%$ of the $\mathrm{K},>89 \%$ of the $\mathrm{Hg}$ and $0.5 \%$ of the Na were extracted by the SREX solvent. $\mathrm{Al}, \mathrm{B}, \mathrm{Cd}, \mathrm{Ca}, \mathrm{Cs}, \mathrm{Cr}, \mathrm{Fe}, \mathrm{Mn}$, and $\mathrm{Ni}$ were determined to be essentially inextractable. A significant percentage of the $\mathrm{Zr}(>81.6 \%)$ and $\mathrm{Ba}$ $(64 \%)$ was extracted. Results obtained from the flowsheet test with actual tank waste were very consistent with results from previous laboratory testing and flowsheet testing with simulated waste solutions.

Data/results of this testing have been independently reviewed by personnel from Argonne National Laboratory (ANL). ANL personnel concur that the testing of the SREX process with actual tank waste was successful and that a full-scale SREX process for the treatment of sodium-bearing waste is viable. 


\section{ACKNOWLEDGEMENTS}

This project was supported by the U.S. Department of Energy Office of Science and Technology's Tanks Focus Area. The authors would also like to acknowledge Phil McGinnis and the TFA Technical Review Group for their support of this program.

The authors would like to thank George Vandegrift and Ralph Leonard of ANL-East for their thorough technical review of the program and experimental results, and for participating in the demonstration.

The authors would also like to express their appreciation to Troy Garn, Carl Lundholm, Rich Tillotson, and Earlen Wade for their assistance with laboratory testing, operation of the centrifugal contactors, chemical makeup, and sample preparations.

Many thanks to Brian Storms, Doug Thompson, Ron Stone, and Dean Goodwin of the Radiochemical Analysis Group, Jeff Laug, Duane Lundholm, and Dennis Nielsen of the Spectrochemical Analysis Group, and the RAL analysts for the efficient, expedient sample analysis.

Without the work and dedication of these people, this test could not have proceeded. 
$:$

-

ㅇ

:

-

-

9

-

8

9

0

○

:ㅇ

-

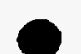

8

-

-

0

웅

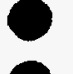

-

9

9

0

0

-

$?$

9

9

0 


\section{CONTENTS}

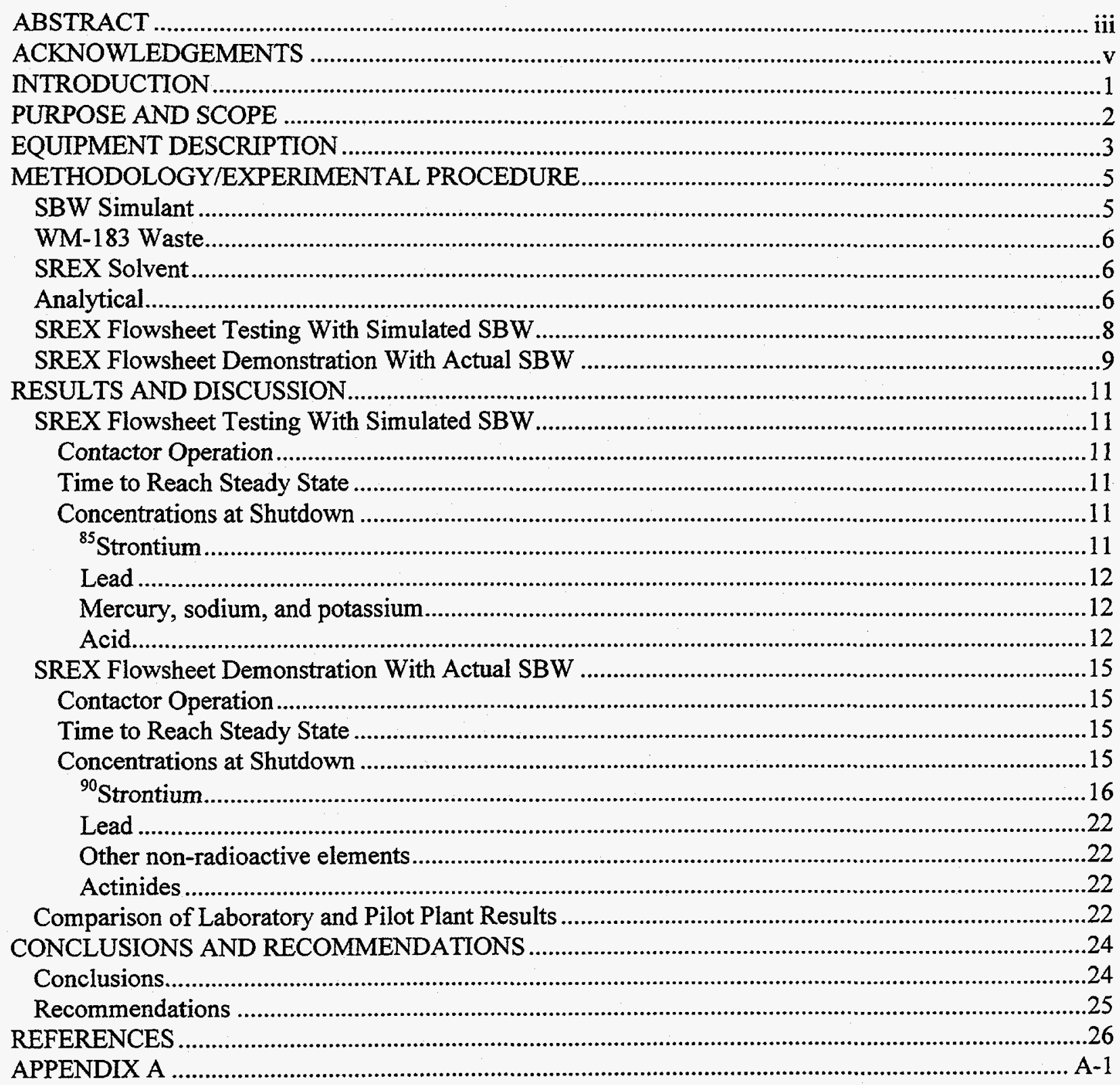




\section{TABLES}

Table 1. Description of the 2-cm centrifugal contactors........................................................................3

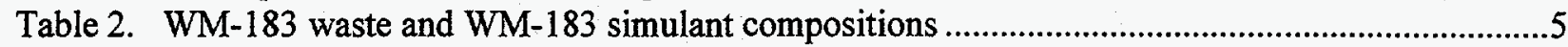

Table 3. Flowrates and O/A ratios for SREX flowsheet testing with simulated SBW..........................11

Table 4. Percentage of component in each of the effluent streams for SREX flowsheet testing with

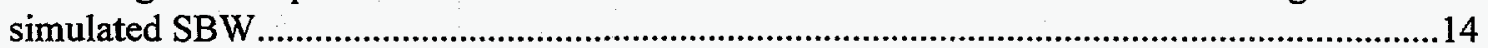

Table 5. ${ }^{85} \mathrm{Sr}$ and $\mathrm{H}^{+}$distribution coefficients for SREX flowsheet testing with simulated SBW...........14

Table 6. Flowrates and O/A ratios for SREX flowsheet testing with WM-183 tank waste. ...................15

Table 7. Percentage of component in each of the effluent streams for SREX flowsheet testing with WM-183 tank waste

Table 8. ${ }^{90} \mathrm{Sr}$, total alpha, $\mathrm{Pb}, \mathrm{Na}$, and $\mathrm{K}$ distribution coefficients for SREX flowsheet testing with WM-183 tank waste .20

Table 9. Comparison of removal efficiencies for flowsheet testing with simulant and WM-183...........23

Table 10. Comparison of distribution coefficients from flowsheet testing and laboratory testing ............23

\section{FIGURES}

Figure 1. 2-cm diameter centrifugal contactors installed in the RAL shielded cell ...............................4

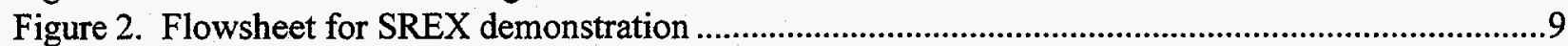

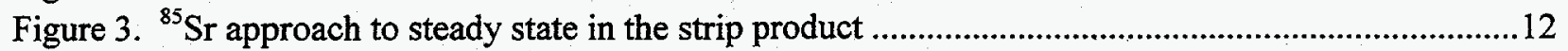

Figure 4. Steady state concentrations for SREX flowsheet testing with simulated SBW ........................13

Figure 5. ${ }^{90} \mathrm{Sr}$ approach to steady state in the aqueous raffinate and strip \#1 product streams..................16

Figure 6. Steady state concentrations for SREX flowsheet testing with WM-183 tank waste.................17

Figure 7. Comparison of experimental results with Generic TRUEX Model results (aqueous phase stage compositions

Figure 8. Comparison of experimental results with Generic TRUEX Model results (organic phase stage compositions 


\section{Demonstration of a SREX Flowsheet for the Partitioning of Strontium and Lead from Actual ICPP Sodium-Bearing Waste}

\section{INTRODUCTION}

The Idaho Chemical Processing Plant (ICPP), located at the Idaho National Engineering and Environmental Laboratory (INEEL), formerly reprocessed spent nuclear fuel to recover fissionable uranium. The radioactive raffinates from the solvent extraction uranium recovery processes were converted to granular solids (calcine) in a high temperature fluidized bed. During the course of reprocessing, a secondary waste stream, liquid sodium-bearing waste (SBW), was also generated primarily from equipment decontamination between campaigns and solvent wash activities. This SBW cannot be directly calcined due to the high sodium content and has historically been blended with reprocessing raffinates or non-radioactive aluminum nitrate prior to calcination. Fuel reprocessing activities are no longer being performed at the ICPP, thereby eliminating the option of waste blending to deplete the SBW inventory. Currently, approximately 5.6 million liters of liquid SBW are temporarily stored at the ICPP in large underground stainless-steel tanks.

The United States Environmental Protection Agency and the Idaho Department of Health and Welfare filed a Notice of Noncompliance in 1992 contending some of the underground waste storage tanks do not meet secondary containment requirements as set forth in Title 40, Part 265.13 of the Code of Federal Regulations. As part of a 1995 agreement between the State of Idaho, the Department of Energy, and the Department of Navy, the SBW must be removed from the tanks by 2012 .

Treatment of the SBW inventories by partitioning the radionuclides and immobilizing the resulting high-activity and low-activity waste streams is currently under evaluation. A recent peer review identified the most promising radionuclide separation technologies for evaluation. ${ }^{1}$ The Transuranic Extraction process, developed by Horwitz and Schulz ${ }^{2}$, was identified as a primary candidate for separation of the actinides from ICPP SBW. The Strontium Extraction (SREX) process, developed by Horwitz $\mathrm{z}^{3-5}$, was identified as a primary candidate for separation of ${ }^{90} \mathrm{Sr}$ from ICPP SBW.

A major emphasis at the ICPP has been directed toward evaluating ${ }^{90} \mathrm{Sr}$ separation from SBW using the SREX process. The active extractant used in the SREX process solvent is $4^{\prime}, 4^{\prime}\left(5^{\prime}\right)$-di-(tertbutyldicyclohexo)-18-crown-6 (DtBuCH18C6). Tributylphosphate (TBP) is added to the solvent as a phase modifier to prevent third phase formation and a paraffinic hydrocarbon is used as a diluent. Considerable laboratory scale experimentation has been performed to evaluate the extraction properties of the SREX solvent with SBW and to develop a SREX flowsheet. ${ }^{6,7}$ Testing of the SREX process with simulated SBW in 5.5-cm centrifugal contactors resulted in $99.98 \%$ removal of $\mathrm{Sr}^{8,9}$ With the test, $\mathrm{Pb}$ was extracted into the SREX solvent and selectively stripped from the solvent with a second strip section (ammonium citrate). Based on the results of the laboratory and pilot-scale testing, a SREX flowsheet demonstration was performed using 24 stages of $2-\mathrm{cm}$ diameter centrifugal contactors. Demonstration of the SREX flowsheet consisted of two parts; 1) flowsheet testing using the 24 stages of centrifugal contactors and simulated SBW spiked with ${ }^{85} \mathrm{Sr}$ and 2) demonstration of the SREX flowsheet using the 24 stages of centrifugal contactors and actual SBW obtained from tank WM-183. The results of these tests are the primary focus of this report. 


\section{PURPOSE AND SCOPE}

The purpose of this study was to demonstrate a SREX flowsheet which will effectively extract and strip ${ }^{90} \mathrm{Sr}$ and $\mathrm{Pb}$ from actual ICPP SBW under continuous, countercurrent conditions. Once the applicability of this process to actual SBW has been established, a comparison of the flowsheet to other technologies currently under development (e.g., cobalt dicarbollide solvent extraction) will be possible. Successful demonstration of the SREX process with SBW will also facilitate the transfer of the technology from EM-50 to EM-30.

A continuous countercurrent flowsheet test was performed using 24 stages of 2-cm diameter centrifugal contactors and simulated SBW spiked with ${ }^{85} \mathrm{Sr}$. This testing was performed in order to verify operation of the SREX process in the 2-cm centrifugal contactors prior to performing the SREX flowsheet demonstration with actual SBW since previous flowsheet testing was performed using 5.5-cm centrifugal contactors. Distribution coefficients and overall removal efficiencies for $\mathrm{Pb}$ and $\mathrm{Sr}$ were evaluated for the flowsheet.

A demonstration of the SREX flowsheet with actual SBW was then performed using the 24 stages of 2-cm centrifugal contactors. The behavior of $\mathrm{Sr}$, the actinides, and the non-radioactive components was evaluated for the flowsheet. Specifically, the ability to achieve the NRC Class A LLW limit of 0.04 $\mathrm{Ci} / \mathrm{m}^{3}$ for ${ }^{90} \mathrm{Sr}$ was evaluated. Potential problems such as solids precipitation, which were not apparent with batch contacting experiments, but could arise because of the solvent loading effects due to the countercurrent solution flow in the centrifugal contactors, were also evaluated. 


\section{EQUIPMENT DESCRIPTION}

Flowsheet testing was performed using 2-cm diameter centrifugal contactors installed in the CPP-684 RAL shielded hot cell. The 2-cm centrifugal contactors, as shown in Figure 1, consist of 24 stages of 2-cm diameter centrifugal contactors, feed and receiving vessels, feed pumps, and an air purge system for the contactor bearings. The aqueous and organic feed pumps and feed vessels were located inside the shielded cell. The remaining feed pumps and feed vessels were located outside the cell. All of the feed pump controllers were located outside the cell. Non-radioactive solutions used for the flowsheet testing were pumped to the centrifugal contactors through penetrations in the cell wall.

The centrifugal contactors were designed and fabricated by Argonne National Laboratory (ANL). The centrifugal contactors were designed specifically for operation of the TRUEX process with ICPP SBW. The contactors were modified at the ICPP for remote installation and operation in the RAL hot cell. Specifically, a modified support structure was fabricated for the contactors. This support structure is portable to allow the contactors to be moved out of the way when not in operation, contains leveling screws to adjust for unevenness in the cell floor, and can be disassembled into three sections. It was necessary to design the support structure for disassembly and reassembly so that the structure would fit through the 12 in. by 22 in. glove box access port into the cell and be assembled remotely. The centrifugal contactors were also installed through the access port in groups of four and assembled on the support structure remotely. Lifting bails were installed on each contactor to facilitate remote replacement or inspection of any motor/rotor assemblies. A description of the centrifugal contactors is provided in Table 1.

Solution was fed to the contactors using valveless metering pumps. Surge lines, consisting of 4-inch sections of 1-inch stainless steel tubing, were placed on the outlet of the pumps to dampen the surging flow. Because of the difficulty associated with remote installation, surge lines were not installed for the aqueous and organic feed pumps located in cell. Flowrates were adjusted by controlling the pump speed using a tenturn potentiometer or by manually adjusting the piston stroke length.

Clear, flexible Teflon ${ }^{\circledast}$ or Teflon ${ }^{\circledast}$ lined Tygon ${ }^{\circledast}$ tubing was used for inlet and outlet connections to the feed and receiving vessels. The feed lines were $1 / 8 \mathrm{in}$. o.d. tubing and the product lines were $3 / 8 \mathrm{in}$. o.d. tubing.

Table 1. Description of the 2-cm centrifugal contactors.
Size
2-cm rotor diameter
Motor
115 Volt, $60 \mathrm{~Hz}$ Bodine Model 710
RPM
3,600 rpm (not adjustable)
Material of construction
304L stainless steel
Inlet and outlet ports
$3 / 8$ in. o.d. tubing
Configuration
Single stage units which can be configured as desired. Stages are connected using U- tubes. 


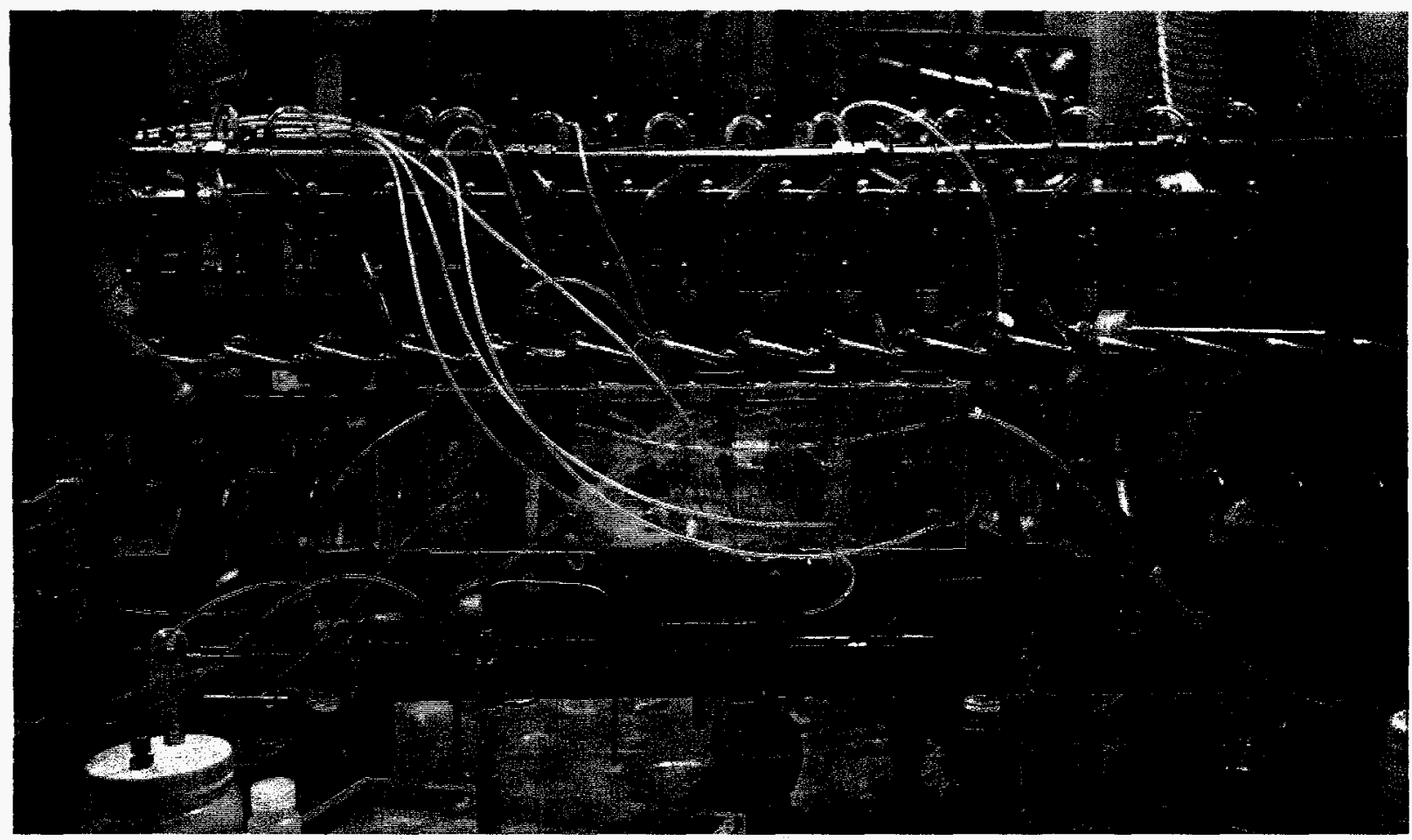

Figure 1. 2-cm diameter centrifugal contactors installed in the RAL shielded cell.

The 2-cm centrifugal contactors do not have provisions for sampling the aqueous and organic solutions exiting individual stages during operation. The aqueous raffinate, strip product, and solvent recycle streams were sampled by routing the solution draining to a receiving vessel into a sample bottle during the actual flowsheet test. Individual stage samples were taken by draining the contactor stages after shutdown.

An air purge system was connected to the contactor bearing housings. Purge air was required in order to protect the motor body, shaft, and bearings from corrosive process fumes. Air to the bearing housings passed through a rotameter. The air flowrate through the rotameter could be adjusted from zero to five scfh. Air from the rotameter was split to feed each of the 24 contactors. The diameter of the air manifold was large ( $1 / 2$ in. o.d. tubing), while the diameter of the tubes leading from the manifold to the contactors was small (1/8 in. o.d. tubing), resulting in the air flow to each contactor being approximately equivalent. The offgas from the bearing purge system was vented to the cell. 


\section{METHODOLOGYIEXPERIMENTAL PROCEDURE}

\section{SBW Simulant}

For the flowsheet testing with simulated SBW, the behavior of ${ }^{85} \mathrm{Sr}$ and the non-radioactive components in simulated SBW was evaluated. Using the analytical results obtained from characterization of SBW waste solution, a non-radioactive simulant was prepared to represent the chemical composition of waste from tank WM-183. ${ }^{85} \mathrm{Sr}$ was added to this simulant and it was used for countercurrent flowsheet testing. WM-183 simulant was chosen for this testing in order to accurately simulate the SREX flowsheet demonstration, for which waste from tank WM-183 was available. The chemical composition of the WM-183 simulant is shown in Table 2.

Table 2. WM-183 waste and WM-183 simulant compositions.

\begin{tabular}{|c|c|c|c|c|c|}
\hline Component & $\begin{array}{l}\text { WM-183 } \\
\text { Simulant }\end{array}$ & $\begin{array}{c}\text { Actual } \\
\text { WM-183 }\end{array}$ & Component & $\begin{array}{l}\text { WM-183 } \\
\text { Simulant }\end{array}$ & $\begin{array}{c}\text { Actual } \\
\text { WM-183 }\end{array}$ \\
\hline Acid $(M)$ & 1.70 & 1.77 & $\mathrm{Ni}(M)$ & 0.034 & 0.0052 \\
\hline $\mathrm{Al}(M)$ & 0.62 & 0.64 & $\mathrm{NO}_{3}(M)$ & 4.8 & -- \\
\hline $\mathrm{B}(M)$ & 0.013 & 0.013 & $\mathrm{~Pb}(M)$ & 0.0015 & 0.0012 \\
\hline $\mathrm{Ca}(M)$ & 0.029 & 0.040 & $\mathrm{SO}_{4}(M)$ & 0.066 & -- \\
\hline $\mathrm{Cd}(M)$ & 0.072 & 0.0012 & $\operatorname{Sr}(M)$ & $6.3 \mathrm{E}-04$ & --- \\
\hline $\mathrm{Cl}(M)$ & 0.011 & -- & $\operatorname{Zr}(M)$ & 0.0065 & $4.2 E-04$ \\
\hline $\mathrm{Cr}(M)$ & 0.017 & 0.014 & Alpha (nCi/g) & $-\cdots$ & 506 \\
\hline $\operatorname{Cs}(M)$ & $9.8 \mathrm{E}-05$ & -- & ${ }^{241} \mathrm{Am}(\mathrm{nCi} / \mathrm{g})$ & -- & 34.9 \\
\hline $\mathrm{F}(M)$ & 0.05 & -- & ${ }^{238} \mathrm{Pu}(\mathrm{nCi} / \mathrm{g})$ & -- & 333.8 \\
\hline $\mathrm{Fe}(M)$ & 0.045 & 0.056 & ${ }^{239} \mathrm{Pu}(\mathrm{nCi} / \mathrm{g})$ & -- & 123.3 \\
\hline $\mathrm{Hg}(M)$ & 0.0013 & 0.0023 & ${ }^{237} \mathrm{~Np}(\mathrm{nCi} / \mathrm{g})$ & -- & -- \\
\hline $\mathrm{K}(M)$ & 0.086 & 0.094 & ${ }^{99} \mathrm{Tc}\left(\mathrm{Ci} / \mathrm{m}^{3}\right)$ & --- & $\cdots$ \\
\hline $\operatorname{Mn}(M)$ & 0.0014 & 0.013 & ${ }^{137} \mathrm{Cs}\left(\mathrm{Ci} / \mathrm{m}^{3}\right)$ & -- & 219 \\
\hline $\operatorname{Mo}(M)$ & 0.049 & 0.001 & ${ }^{90} \mathrm{Sr}\left(\mathrm{Ci} / \mathrm{m}^{3}\right)$ & -- & 201 \\
\hline $\mathrm{Na}(M)$ & 0.69 & 0.68 & ${ }^{85} \mathrm{Sr}\left(\mathrm{Ci} / \mathrm{m}^{3}\right)$ & 0.05 & -- \\
\hline
\end{tabular}




\section{WM-183 Waste}

Sodium-bearing waste, obtained from tank WM-183 in 1996, was used as feed solution for the SREX flowsheet demonstration. The WM- 183 waste solution was passed through a 0.45 micron filter prior to flowsheet testing. Currently, approximately 5.6 million liters of SBW are stored in six tanks. The composition in each tank varies; however, the composition of the solution in tank WM-183 is representative of the solution in all the tanks. The chemical composition of the WM-183 is shown in Table 2.

\section{SREX Solvent}

The SREX solvent composition used in all SREX flowsheet studies reported herein was $0.15 \mathrm{M}$ 4',4'(5')-di-(tert-butyldicyclohexo)-18-crown-6 and $1.5 \mathrm{M}$ TBP in Isopar- $\mathrm{L}^{\circledR}$ and was prepared by the ICPP Quality Control Laboratory. The extractant was obtained from Eichrom Industries, Darien, Il. The performance of this extractant is extremely sensitive to the purity of the product. The extractant used in these tests was reported to yield $a \mathrm{D}_{\mathrm{sr}}$ value of 3.8 according to Eichrom quality assurance procedures. The SREX process was originally developed using 1-octanol as the diluent. This selection was made because the flash point and flammability of this diluent were determined to present minimal risk in a process operation. However, octanol is known to form degradation products when placed in contact with nitric acid. The degradation products present unknown potential safety problems in the operation of the SREX process. In addition, it has been determined that the residual presence of 1-octanol in the aqueous phase decreases the performance of CMPO in actinide removal in the TRUEX process during sequential waste treatment processes. An alternative diluent, therefore, has been studied to replace 1-octanol. The alternative solvent is composed of an isoparaffinic hydrocarbon diluent (Isopar- $\mathrm{L}^{\circledR}$ from Exxon Corp.) and 1.5 M TBP as a phase modifier. This solvent is compatible with the TRUEX solvent currently being studied at the ICPP.

The purity and composition of the SREX solvent were established prior to use in the centrifugal contactors. $\mathrm{D}_{\mathrm{Sr}}$ was determined using the SREX solvent and 3.0 M nitric acid solution in order to evaluate solvent purity and composition. This method of determining the strontium distribution coefficient was established as a quality control procedure for testing the initial SREX solvent and the SREX solvent product from each flowsheet test. If the results were within the acceptable range $\left(D_{\mathrm{Sr}}>\right.$ 2.5 ), the solvent was considered suitable for extraction studies.

Prior to performing the flowsheet testing, the SREX solvent was pre-equilibrated with $\mathrm{HNO}_{3}$ by contacting the solvent with $3 \mathrm{MHNO}_{3}$ twice at an $\mathrm{O} / \mathrm{A}=1$. With this pre-equilibration, the $\mathrm{HNO}_{3}$ concentration of the SREX solvent feed was approximately $1.0 \mathrm{M}$. Pre-equilibration of the solvent prevents the extraction of $\mathrm{HNO}_{3}$ from the acidic waste, which would result in lower ${ }^{90} \mathrm{Sr}$ distribution coefficients in the extraction section.

\section{Analytical}

The countercurrent extraction tests which were performed resulted in a considerable number of samples requiring analysis. Analyses for this testing included ${ }^{90} \mathrm{Sr},{ }^{85} \mathrm{Sr}$, total alpha, ${ }^{241} \mathrm{Am},{ }^{238} \mathrm{Pu},{ }^{239} \mathrm{Pu}$, $\mathrm{U},{ }^{137} \mathrm{Cs},{ }^{99} \mathrm{Tc}, \mathrm{Al}, \mathrm{Ba}, \mathrm{B}, \mathrm{Cd}, \mathrm{Ca}, \mathrm{Cr}, \mathrm{Fe}, \mathrm{H}^{+}, \mathrm{Pb}, \mathrm{Mn}, \mathrm{Hg}, \mathrm{Ni}, \mathrm{K}, \mathrm{Na}$, and $\mathrm{Zr}$. Gas flow proportional counting was used for ${ }^{90} \mathrm{Sr}$ analyses, gamma spectroscopy was used for ${ }^{137} \mathrm{Cs}$ and ${ }^{85} \mathrm{Sr}$ analyses, alpha spectroscopy was used for $\mathrm{Am}$ and $\mathrm{Pu}$ analyses, mass spectroscopy was used for $\mathrm{U}$ analyses, and liquid scintillation counting was used for Tc analyses. Inductively coupled plasma atomic emission 
spectroscopy (ICP-AES) was used for $\mathrm{Al}, \mathrm{Ba}, \mathrm{B}, \mathrm{Cd}, \mathrm{Ca}, \mathrm{Cr}, \mathrm{Fe}, \mathrm{Mn}, \mathrm{Ni}$, and $\mathrm{Zr}$ analyses, atomic fluorescence spectroscopy for $\mathrm{Hg}$ analyses, and atomic absorption spectrophotometry (AAS) for $\mathrm{Na}$ and $\mathrm{K}$ analyses.

For the testing with actual waste solution, most organic and aqueous samples were diluted prior to removal from the RAL hot cell due to their intense radioactivity. Aqueous dilutions were made in 3 volume $\% \mathrm{HNO}_{3}$ and organic dilutions were made in unused solvent. Dilutions as great as $0.5 \mathrm{mLs}$ to $100.5 \mathrm{mLs}$ were needed to bring the samples out of the hot cell. Additional dilutions on some aqueous samples were required for analytical, as opposed to radiological, purposes.

Analysis of the organic samples could not be performed directly. Therefore, the components of interest were stripped from the organic samples and the resulting aqueous strip solution was submitted for analysis. Previous experimental work indicated that $\mathrm{Al}, \mathrm{Ba}, \mathrm{B}, \mathrm{Cd}, \mathrm{Ca}, \mathrm{Cr}, \mathrm{Fe}, \mathrm{Pb}, \mathrm{Mn}, \mathrm{Ni}, \mathrm{K}, \mathrm{Na}, \mathrm{Zr}$, and the actinides are effectively back-extracted from the SREX solvent with solutions of ammonium citrate, and $\mathrm{Hg}$ is effectively back-extracted with solutions of EDTA. ${ }^{6-9}$ Consequently, the SREX solvent samples were contacted first with $0.1 \mathrm{M}$ ammonium citrate and then with $0.1 \mathrm{MEDTA}$. The resulting aqueous solutions were used for the indirect analysis of the organic phase. An organic to aqueous (O/A) phase ratio of 0.2 was used in these contacts to insure quantitative recovery of extracted species from the organic phase occurred in a single contact.

${ }^{90} \mathrm{Sr}$ analyses were performed by separation with the classical fuming nitric acid technique. Strontium was precipitated as $\mathrm{SrCO}_{3}$ and filtered onto a $24-\mathrm{mm}$ glass microfiber filter. The ${ }^{90} \mathrm{Sr}$ on the filter was then analyzed by gas-flow proportional counting. Samples were counted immediately after separation to eliminate the need for correction due to the ingrowth of the ${ }^{90} \mathrm{Y}$ daughter of ${ }^{90} \mathrm{Sr}$.

Gross alpha analyses were performed on all aqueous samples, as well as the aqueous solutions resulting from the ammonium citrate strips performed on the organic samples. Gross alpha analyses were performed by evaporating $1 \mathrm{~mL}$ of each sample on a 52-mm stainless steel counting planchet. The samples were counted by a gas flow proportional counter (Tennelec LB-5100) at a bias of 610 volts. This voltage is within the recombination region for beta emissions to effectively eliminate crosstalk from the beta constituents.

Americium and plutonium analyses were performed by partitioning these two actinides from one another using extraction chromatography. TEVA Resin ${ }^{\circledR}$ and TRU Resin ${ }^{\circledR}$ columns were placed sequentially and sample aliquots were passed through the columns. Plutonium (and neptunium) was partitioned onto the TEVA Resin ${ }^{\circledast}$ column while americium passed through the TEVA Resin ${ }^{\circledR}$ column and was extracted onto the TRU Resin ${ }^{\circledR}$ column, along with $\mathrm{UO}_{2}{ }^{+2}$. Plutonium was removed from the TEVA Resin ${ }^{\circledR}$ column with $0.5 \mathrm{MHCl}$, and americium was removed from the TRU Resin ${ }^{\circledR}$ column with $0.025 \mathrm{MHNO}_{3}$. Uranium was removed from the TRU Resin ${ }^{\circledR}$ column with $0.1 \mathrm{M}$ ammonium oxalate. The sample aliquots were spiked with NIST ${ }^{236} \mathrm{Pu}$ and ${ }^{243} \mathrm{Am}$ prior to separation by extraction chromatography so that analytical yields could be determined. Tracer yields were used to calculate total isotopic activity reported for each sample.

Technetium was chemically separated from the samples and quantified by liquid scintillation counting (LSC). A rigorous radionuclide separation procedure was performed to prevent erroneous LSC results. Sodium bisulfite was first added to a sample aliquot to reduce $\mathrm{I}^{-}$, followed by sodium nitrite addition to oxidize $\mathrm{I}^{-}$to $\mathrm{I}_{2}$. Radioiodine was volatilized as $\mathrm{I}_{2}$ by taking the samples to dryness and bringing them back to volume with $0.1 \mathrm{MHNO}_{3}$. Cesium and strontium were removed by oxidizing the sample aliquots with hydrogen peroxide and passing them through a Dowex $50 \mathrm{X}$ cation exchange 
column. The sample exiting the column was taken to dryness and brought back to solution with $3.0 \mathrm{M}$ $\mathrm{H}_{2} \mathrm{SO}_{4}$. Technetium was extracted from sulfuric acid with TBP that was previously pre-equilibrated with unused 3.0 $\mathrm{MH}_{2} \mathrm{SO}_{4}$. Aliquots of the TBP were counted using a Packard Tricarb 2500 Liquid Scintillation Spectrometer. Activity values were calibrated using a curve of counting efficiency versus quench. Duplicate Tc samples were analyzed, one being spiked with a known ${ }^{99} \mathrm{Tc}$ activity. The spiked and unspiked samples were processed simultaneously for consistency. Chemical yields were calculated from the spiked samples and used to account for Tc loss during the analytical separation process.

\section{SREX Flowsheet Testing With Simulated SBW}

Based on the results of previous SREX flowsheet development studies performed in the 5.5$\mathrm{cm}$ Centrifugal Contactor Mockup and results of batch laboratory extraction experiments, ${ }^{6-9} \mathrm{a}$ SREX flowsheet was recommended for testing in the 2-cm centrifugal contactors. This flowsheet consists of ten stages of extraction at an O/A of 1.0, two stages of $2 M \mathrm{HNO}_{3}$ scrub at an O/A of 4.0, four stages of $0.05 M \mathrm{HNO}_{3}$ strip at an $\mathrm{O} / \mathrm{A}$ of 0.5 , four stages of $0.1 \mathrm{M}$ ammonium citrate strip at an O/A of 1.0, and four stages of $3.0 \mathrm{MHNO}_{3}$ rinse at an O/A of 2.0. The resulting flowsheet used for the SREX flowsheet testing with SBW simulant is shown in Figure 2.

The goals of the SREX flowsheet testing were to:

(1) Demonstrate the overall operability of the 2-cm centrifugal contactors with the SREX flowsheet prior to performing the SREX demonstration with actual tank waste.

(2) Determine the removal efficiency of ${ }^{85} \mathrm{Sr}$ for the SREX flowsheet.

(3) Evaluate the effectiveness of the SREX flowsheet in stripping $\mathrm{Pb}$ from the SREX solvent.

(4) Determine if any precipitate or third phase formation problems exist with this flowsheet.

SREX flowsheet testing was performed as follows. The centrifugal contactor motors were started at $3,600 \mathrm{rpm}$. All aqueous solution flows, except for the SBW simulant, were established. A solution of 1.7 $M \mathrm{HNO}_{3}, 0.6 \mathrm{MAl}_{2}\left(\mathrm{NO}_{3}\right)_{3}$, and $0.6 \mathrm{MNaNO}_{3}$ was used as an initial SBW feed. When aqueous solution was observed exiting each of the sections, solvent flow was initiated. SBW simulant feed (spiked with ${ }^{85} \mathrm{Sr}$ ) was started when solvent was observed exiting the acidification section (stage 24 ). Samples were taken from the aqueous raffinate and strip \#1 product at intervals of $30,60,90$, and 120 minutes after the start of the SBW feed. Level readings on each of the feed tanks were also noted in order to determine actual solution flowrates based on tank depletion rates. Approximately 150 minutes after the start of SBW feed, samples were taken of the aqueous raffinate, strip \#1 product, strip \#2 product, acidification effluent, and solvent effluent streams. The centrifugal contactors were then shutdown by simultaneously stopping the feed pumps and contactor motors. Each stage remains approximately at steady-state operating conditions with this type of shutdown. This allowed aqueous and organic samples to be taken from each stage and, therefore, distribution coefficients to be determined for any of the 24 stages.

After shutdown, individual stage samples were taken as follows. The solution from each stage was drained into individual $60 \mathrm{~mL}$ sample bottles. The phases were re-equilibrated by shaking the bottles with a manipulator for several minutes each. Re-equilibration of the phases serves to evaluate distribution coefficients of the individual species under hypothetical conditions of $100 \%$ stage efficiency. The re-equilibrated solution from each stage was then poured into a clean separatory funnel, allowed to stand for five to ten minutes, and the aqueous and organic phases were separated. 


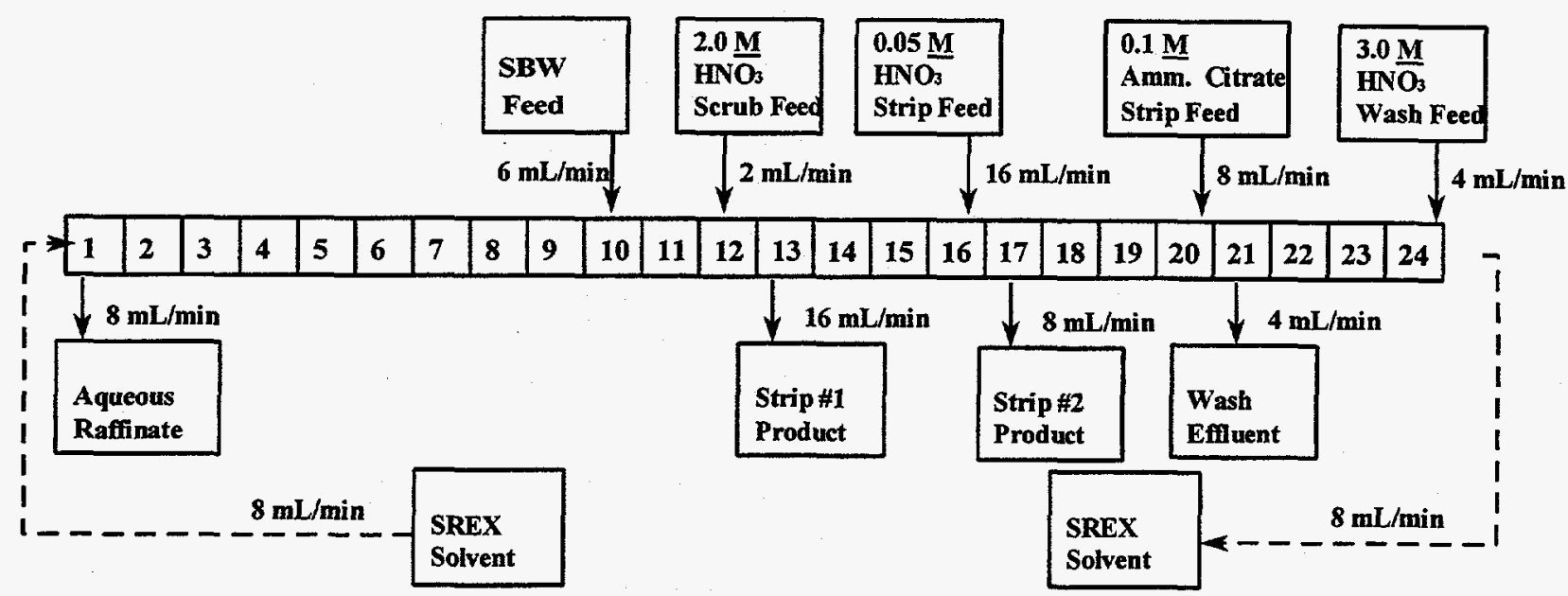

Figure 2. Flowsheet for SREX demonstration.

\section{SREX Flowsheet Demonstration With Actual SBW}

Based on the results of the SREX flowsheet testing with SBW simulant in the 2-cm centrifugal contactors, the same flowsheet was tested with actual SBW from tank WM-183 (see Figure 2). The goals of the SREX demonstration were to:

(1) Demonstrate the overall operability of the 2-cm centrifugal contactors with the SREX flowsheet using actual tank waste.

(2) Determine the removal efficiencies and distribution coefficients of ${ }^{90} \mathrm{Sr}$, the actinides, and the nonradioactive components for the SREX flowsheet.

(3) Evaluate the ability of the SREX flowsheet to decontaminate the tank waste to below the NRC Class A LLW requirement of $0.04 \mathrm{Ci} / \mathrm{m}^{3}$ for ${ }^{90} \mathrm{Sr}$.

(4) Evaluate the effectiveness of the SREX flowsheet in selectively stripping $\mathrm{Pb}$ and ${ }^{90} \mathrm{Sr}$ from the SREX solvent.

(5) Determine if any precipitate or third phase formation problems exist with this flowsheet.

SREX flowsheet testing was performed as follows. The centrifugal contactor motors were started at $3,600 \mathrm{rpm}$. All aqueous solution flows, except for the WM-183 waste, were established. A solution of $1.7 \mathrm{MHNO}_{3}, 0.6 \mathrm{M} \mathrm{Al}_{2}\left(\mathrm{NO}_{3}\right)_{3}$, and $0.6 \mathrm{MNaNO}_{3}$ was used as an initial SBW feed. When aqueous solution was observed exiting each of the sections, solvent flow was initiated. WM-183 feed was started when solvent was observed exiting the acidification section (stage 24). Samples were taken from the aqueous raffinate and strip \#1 product at intervals of $30,60,90$, and 120 minutes after the start of the SBW feed. Level readings on each of the feed tanks were also noted in order to determine actual solution flowrates based on tank depletion rates. Approximately 150 minutes after the start of SBW feed, samples were taken of the aqueous raffinate, strip \#1 product, strip \#2 product, acidification effluent, and solvent effluent streams. The centrifugal contactors were then shutdown by simultaneously stopping the feed pumps and contactor motors. Each stage remains approximately at steady-state operating conditions with this type of shutdown. This allowed aqueous and organic samples to be taken from each stage and, therefore, distribution coefficients to be determined for any of the 24 stages. 
After shutdown, individual stage samples were taken as follows. The solution from each stage was drained into individual $60 \mathrm{~mL}$ sample bottles. The phases were re-equilibrated by shaking the bottles with a manipulator for several minutes each. Re-equilibration of the phases serves to evaluate distribution coefficients of the individual species under hypothetical conditions of $100 \%$ stage efficiency. The re-equilibrated solution from each stage was then poured into a clean separatory funnel, allowed to stand for five to ten minutes, and the aqueous and organic phases were separated. 


\section{RESULTS AND DISCUSSION}

\section{SREX Flowsheet Testing With Simulated SBW}

\section{Contactor Operation}

Actual solution flowrates were calculated from feed tank depletion rates and are compared to the desired flowrates in Table 3. Precipitate and/or third phase formation were not observed during testing or after shutdown. Also, no observable flooding occurred.

Table 3. Flowrates and O/A ratios for SREX flowsheet testing with simulated SBW.

\begin{tabular}{lcccccc}
\multirow{2}{*}{ Section } & \multicolumn{2}{c}{ Flowrate $(\mathrm{mL} / \mathrm{min})$} & \multicolumn{2}{c}{ O/A Ratio } & Total Flow \\
& Phase & Desired & Actual & Desired & Actual & (mL/min) \\
All & Org. & 8.0 & 7.8 & $\cdots$ & $\cdots$ & $\cdots$ \\
Extraction & Aq. & 6.0 & 5.7 & 1.0 & 1.0 & 15.5 \\
Scrub & Aq. & 2.0 & 2.0 & 4.0 & 3.9 & 9.8 \\
Strip \#1 & Aq. & 16.0 & 16.0 & 0.5 & 0.49 & 23.8 \\
Strip \#2 & Aq. & 8.0 & 8.4 & 1.0 & 0.93 & 16.2 \\
HNO $_{3}$ Equilib. & Aq. & 4.0 & 3.8 & 2.0 & 2.1 & 11.6 \\
\hline
\end{tabular}

\section{Time to Reach Steady State}

The activity of ${ }^{85} \mathrm{Sr}$ as a function of time $\left(\mathrm{T}_{0}=\right.$ start of spiked SBW simulant feed flow) is given in Figure 3 for the strip \#1 product. The activity of ${ }^{85} \mathrm{Sr}$ as a function of time for the raffinate stream is not shown because all analytical results were below the detection limit. Steady state for ${ }^{85} \mathrm{Sr}$ in the strip \#1 product was reached within 30 minutes. It was assumed that steady state was reached when the activity of ${ }^{85} \mathrm{Sr}$ varied by less than ten percent.

\section{Concentrations at Shutdown}

The concentrations of ${ }^{85} \mathrm{Sr}, \mathrm{Pb}, \mathrm{H}^{+}, \mathrm{Na}, \mathrm{K}$, and $\mathrm{Hg}$ in each stream immediately prior to shutdown are given in Figure 4. Material balances for ${ }^{85} \mathrm{Sr}, \mathrm{Pb}, \mathrm{Na}, \mathrm{K}$, and $\mathrm{Hg}$ are given in Table 4. The values in Table 4 were normalized to obtain an overall material balance of $100 \%$. Distribution coefficients were calculated for ${ }^{85} \mathrm{Sr}$ and $\mathrm{H}^{+}$for several of the 24 stages. The resulting distribution coefficients are given in Table 5. A discussion of the behavior of each component follows.

${ }^{85}$ Strontium. The ${ }^{85} \mathrm{Sr}$ activity was reduced from $1.98 \mathrm{E}+03 \mathrm{dps} / \mathrm{mL}$ in the feed to $<0.54 \mathrm{dps} / \mathrm{mL}$ in the raffinate. This corresponds to greater than $99.96 \%{ }^{85} \mathrm{Sr}$ removal. The activity of ${ }^{85} \mathrm{Sr}$ was below the analytical detection limit in the raffinate. Consequently, the actual removal efficiency could not be determined. Distribution coefficients in the extraction section ranged from $>4.1$ to 8.1 , which is higher 


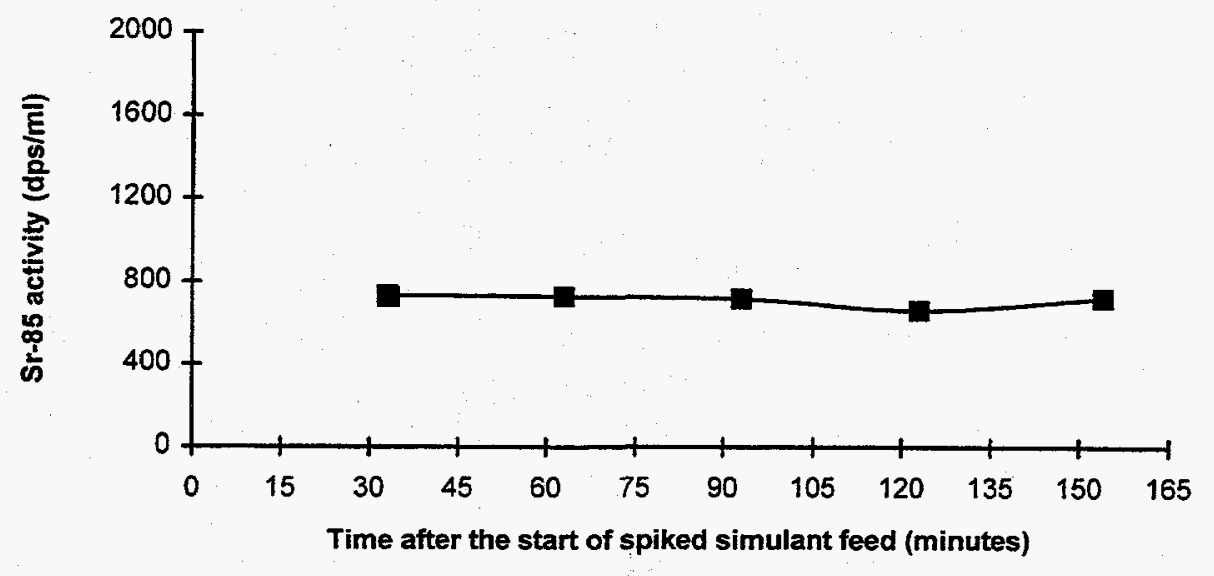

Figure $3 .{ }^{85} \mathrm{Sr}$ approach to steady state in the strip product.

than results from previous testing $\left(\mathrm{D}_{\mathrm{Sr}}=2\right.$ to 3$) .{ }^{8,9}$ The higher distribution coefficients for this testing are attributed to the lower $\mathrm{Na}$ and $\mathrm{K}$ concentrations in the WM-183 simulant as compared to the simulant used in previous testing, the slightly higher nitrate concentration of the WM-183 as compared to the simulant used previously ( $4.8 \mathrm{M}$ vs. $4.5 \mathrm{M}$ ), and the higher purity solvent used for this testing.

The $0.05 \mathrm{M}$ nitric acid strip section was very effective in back-extracting the ${ }^{85} \mathrm{Sr}$ from the SREX solvent, resulting in $>99.97 \%$ of the ${ }^{85} \mathrm{Sr}$ being stripped from the SREX solvent with the four strip stages. As a result, $<0.04 \%$ of the ${ }^{85} \mathrm{Sr}$ in the feed exited with the strip \#2 product ( $\mathrm{Pb}$ strip).

Lead. The SREX solvent extracted greater than $99.97 \%$ of the $\mathrm{Pb}$ from the SBW simulant. The first strip section $\left(0.05 \mathrm{MHNO}_{3}\right)$ back-extracted $7.9 \%$ of the $\mathrm{Pb}$ from the SREX solvent. The ammonium nitrate strip section effectively back-extracted the remaining $92.1 \%$ of the $\mathrm{Pb}$. Based on previous flowsheet testing, ${ }^{9}$ it was expected that less than $2 \%$ of the $\mathrm{Pb}$ would exit with the strip \#1 product. Stage samples were not analyzed for $\mathrm{Pb}$ so distribution coefficients could not be evaluated to help determine why the quantity of $\mathrm{Pb}$ back-extracted by the dilute $\mathrm{HNO}_{3}$ strip solution was larger than expected.

Mercury, sodium, and potassium. As expected, $\mathrm{Hg}$ and $\mathrm{K}$ were extracted from the SBW $(99.99 \%$ of the $\mathrm{Hg}$ and $39 \%$ of the $\mathrm{K}$ ) and very little $(0.1 \%)$ of the $\mathrm{Na}$ was extracted from the SBW. It was expected that the $\mathrm{K}$ would be scrubbed from the SREX solvent with the $2 M \mathrm{HNO}_{3}$. However, distribution coefficients of approximately 1.0 were obtained in the scrub section, resulting in little of the $\mathrm{K}$ being scrubbed from the solvent. The $\mathrm{K}$ was effectively stripped from the SREX solvent with the 0.05 $M \mathrm{HNO}_{3}$ strip section. The $\mathrm{Hg}$ was not effectively stripped from the solvent. Only $9.5 \%$ of the $\mathrm{Hg}$ was stripped from the solvent with the two strip sections. The remaining $90.5 \%$ of the $\mathrm{Hg}$ exited with the solvent effluent.

Acid. Distribution coefficients for $\mathrm{H}^{+}$ranged from 0.60 to 0.65 in the extraction section and 0.38 to 0.41 in the scrub section and first stage of the nitric acid strip section. These distribution coefficients are in good agreement with $\mathrm{H}^{+}$data from previous SREX testing. ${ }^{8}, 9$ 


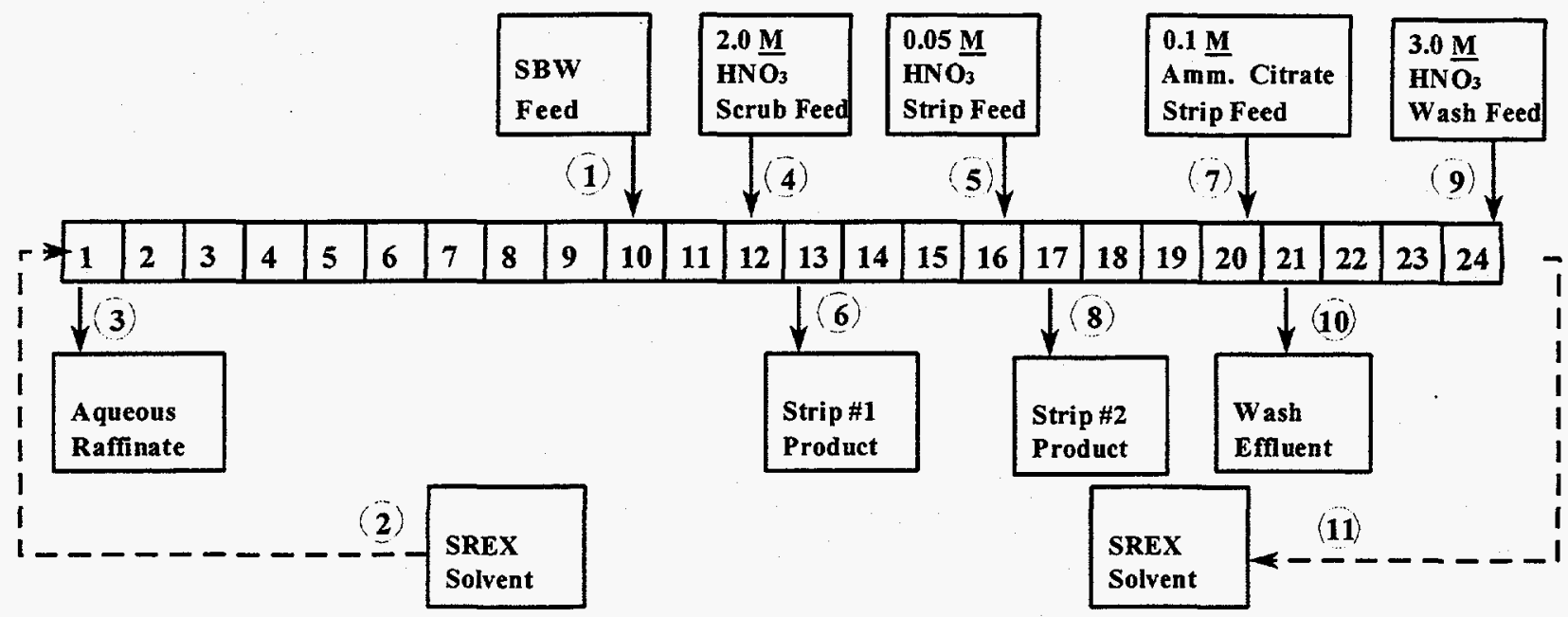

\begin{tabular}{|c|c|c|c|c|c|c|c|c|c|c|c|}
\hline Component & $\begin{array}{c}\text { SBW } \\
\text { Feed } \\
1\end{array}$ & $\begin{array}{c}\text { SREX } \\
\text { Solvent } \\
\text { Feed } \\
2\end{array}$ & $\begin{array}{c}\text { LAW } \\
\text { Raff. } \\
3\end{array}$ & $\begin{array}{c}\text { Scrub } \\
\text { Feed } \\
4\end{array}$ & $\begin{array}{c}\text { Strip \#1 } \\
\text { Feed } \\
5\end{array}$ & $\begin{array}{c}\text { Strip \#1 } \\
\text { Product } \\
6\end{array}$ & $\begin{array}{c}\text { Strip } \# 2 \\
\text { Feed } \\
7\end{array}$ & $\begin{array}{c}\text { Strip \#2 } \\
\text { Product } \\
8\end{array}$ & $\begin{array}{c}\mathrm{HNO}_{3} \\
\text { Feed } \\
9\end{array}$ & $\begin{array}{c}\mathrm{HNO}_{3} \\
\text { Effluent } \\
10\end{array}$ & $\begin{array}{c}\text { SREX } \\
\text { Solvent } \\
\text { Effluent } \\
11\end{array}$ \\
\hline $\mathrm{H}^{+}(M)$ & 1.7 & -- & 1.84 & 2.0 & 0.05 & 0.72 & -- & -- & 3.0 & --- & -- \\
\hline Amm. citrate $(M)$ & --- & -- & -- & --- & --- & --- & 0.1 & -- & --- & -- & - \\
\hline${ }^{85} \mathrm{Sr}(\mathrm{dps} / \mathrm{mL})$ & $1.98 \mathrm{E}+03$ & --- & $<0.54$ & --- & -- & 720 & - & $<0.51$ & $-\cdots$ & $<0.55$ & $<0.53$ \\
\hline $\mathrm{Pb}(M)$ & $1.47 \mathrm{E}-03$ & -- & $<3.8 \mathrm{E}-07$ & -- & $\ldots$ & $4.56 \mathrm{E}-05$ & - & $1.01 \mathrm{E}-03$ & -- & $<3.8 \mathrm{E}-07$ & $<3.8 \mathrm{E}-07$ \\
\hline $\mathrm{Na}(M)$ & 0.69 & -- & 0.50 & --- & - & $1.61 \mathrm{E}-04$ & - & $1.48 \mathrm{E}-06$ & - & 4.00E-06 & $2.26 \mathrm{E}-06$ \\
\hline $\mathrm{K}(M)$ & 0.086 & - & 0.041 & -- & -- & 0.013 & -- & $2.19 \mathrm{E}-05$ & --- & $<7.7 \mathrm{E}-07$ & $7.16 \mathrm{E}-07$ \\
\hline $\mathrm{Hg}(M)$ & $1.28 \mathrm{E}-03$ & -- & $9.10 \mathrm{E}-08$ & -- & --- & $2.36 \mathrm{E}-06$ & -- & $9.92 \mathrm{E}-05$ & -- & $2.00 \mathrm{E}-07$ & $1.07 \mathrm{E}-03$ \\
\hline Flowrate (mL/min) & 5.7 & 7.8 & 7.7 & 2.0 & 16.0 & 16.0 & 8.4 & 8.4 & 3.8 & 3.8 & 7.8 \\
\hline
\end{tabular}

Figure 4. Steady state concentrations for SREX flowsheet testing with simulated SBW. 
Table 4. Percentage of component in each of the effluent streams for SREX flowsheet testing with simulated SBW.

\begin{tabular}{|c|c|c|c|c|c|}
\hline Stream & ${ }^{85} \mathrm{Sr}$ & $\mathrm{Pb}$ & $\mathrm{Hg}$ & $\mathrm{Na}$ & $\mathrm{K}$ \\
\hline Aqueous Raffinate & $\begin{array}{c}<0.037 \% \\
(<0.036 \%)^{a}\end{array}$ & $\begin{array}{c}<0.035 \% \\
(<0.032 \%)\end{array}$ & $\begin{array}{c}0.01 \% \\
(0.008 \%)\end{array}$ & $\begin{array}{c}99.3 \% \\
(99.9 \%)\end{array}$ & $\begin{array}{c}64.4 \% \\
(60.9 \%)\end{array}$ \\
\hline Strip \#1 Product & $\begin{array}{c}101.8 \% \\
(>99.87 \%)\end{array}$ & $\begin{array}{r}8.6 \% \\
(7.9 \%)\end{array}$ & $\begin{array}{c}0.51 \% \\
(0.41 \%)\end{array}$ & $\begin{array}{c}0.065 \% \\
(0.066 \%)\end{array}$ & $\begin{array}{c}41.3 \% \\
(39.1 \%)\end{array}$ \\
\hline Strip \#2 Product & $\begin{array}{l}<0.04 \% \\
(<0.04 \%)\end{array}$ & $\begin{array}{l}100.9 \% \\
(92.0 \%)\end{array}$ & $\begin{array}{l}11.3 \% \\
(9.0 \%)\end{array}$ & $\begin{array}{c}0.0003 \% \\
(0.0003 \%)\end{array}$ & $\begin{array}{c}0.037 \% \\
(0.035 \%)\end{array}$ \\
\hline $\begin{array}{l}\text { Nitric Acid } \\
\text { Effluent }\end{array}$ & $\begin{array}{c}<0.02 \% \\
(<0.02 \%)\end{array}$ & $\begin{array}{c}<0.02 \% \\
(<0.02 \%)\end{array}$ & $\begin{array}{c}0.01 \% \\
(0.008 \%)\end{array}$ & $\begin{array}{c}0.0004 \% \\
(0.0004 \%)\end{array}$ & $\begin{array}{c}<0.0005 \% \\
(<0.0005 \%)\end{array}$ \\
\hline $\begin{array}{l}\text { Solvent } \\
\text { Effluent }\end{array}$ & $\begin{array}{l}<0.04 \% \\
(<0.04 \%)\end{array}$ & $\begin{array}{l}<0.03 \% \\
(<0.03 \%)\end{array}$ & $\begin{array}{l}113.6 \% \\
(90.5 \%)\end{array}$ & $\begin{array}{c}0.0004 \% \\
(0.0004 \%)\end{array}$ & $\begin{array}{c}0.001 \% \\
(0.001 \%)\end{array}$ \\
\hline Mass Balance ${ }^{b}$ & $101.9 \%$ & $109.6 \%$ & $125.5 \%$ & $99.4 \%$ & $105.7 \%$ \\
\hline
\end{tabular}

Table 5. ${ }^{85} \mathrm{Sr}$ and $\mathrm{H}^{+}$distribution coefficients for SREX flowsheet testing with simulated SBW.

\begin{tabular}{lcll}
\hline Section & Stage & $\mathrm{D}_{\mathrm{Sr}}$ & $\mathrm{D}_{\mathrm{H}^{+}}$ \\
\hline \multirow{2}{*}{ Extraction } & 1 & $\mathrm{nd}^{\mathrm{a}}$ & nd \\
& 3 & $\mathrm{nd}$ & 0.65 \\
& 5 & $>4.06$ & 0.65 \\
& 8 & 7.9 & 0.59 \\
Scrub & 10 & 8.1 & 0.63 \\
& 11 & 7.0 & 0.38 \\
Strip \#1 & 12 & 6.0 & 0.40 \\
& 13 & 1.0 & 0.41 \\
Strip \#2 & 15 & $<0.05$ & nd \\
& 17 & nd & nd \\
\hline a. Not determined. & 19 & nd & nd \\
\hline
\end{tabular}




\section{SREX Flowsheet Demonstration With Actual SBW}

\section{Contactor Operation}

Actual solution flowrates were calculated from feed tank depletion rates and are compared to the desired flowrates in Table 6. Precipitate and/or third phase formation were not observed during testing or after shutdown. Also, flooding was not observed during testing.

Table 6. Flowrates and O/A ratios for SREX flowsheet testing with WM-183 tank waste.

\begin{tabular}{|c|c|c|c|c|c|c|}
\hline \multirow[b]{2}{*}{ Section } & \multirow[b]{2}{*}{ Phase } & \multicolumn{2}{|c|}{ Flowrate $(\mathrm{mL} / \mathrm{min})$} & \multicolumn{2}{|c|}{ O/A Ratio } & \multirow{2}{*}{$\begin{array}{l}\text { Total Flow } \\
\text { (mL/min) }\end{array}$} \\
\hline & & Desired & Actual & Desired & Actual & \\
\hline All & Org. & 8.0 & 8.2 & --- & --- & $\ldots$ \\
\hline Extraction & Aq. & 6.0 & 5.8 & 1.0 & 1.05 & 16.0 \\
\hline Scrub & Aq. & 2.0 & 2.0 & 4.0 & 4.1 & 10.2 \\
\hline Strip \#1 & Aq. & 16.0 & 15.1 & 0.5 & 0.54 & 23.3 \\
\hline Strip \#2 & Aq. & 8.0 & 7.9 & 1.0 & 1.04 & 16.1 \\
\hline $\mathrm{HNO}_{3}$ Equilib. & Aq. & 4.0 & 4.0 & 2.0 & 2.05 & 12.2 \\
\hline
\end{tabular}

\section{Time to Reach Steady State}

The activity of ${ }^{90} \mathrm{Sr}$ as a function of time $\left(\mathrm{T}_{0}=\right.$ start of WM-183 feed) is given in Figure 5 for the strip \#1 product and aqueous raffinate streams. It was assumed that steady state was reached when the activity of ${ }^{85} \mathrm{Sr}$ varied by less than ten percent. Steady state for ${ }^{90} \mathrm{Sr}$ in the strip \#1 product was reached within 30 minutes. Except for the sample taken at 154 minutes, steady state for ${ }^{90} \mathrm{Sr}$ in the raffinate was reached within 90 minutes. The raffinate sample taken at 154 minutes is expected to have the same ${ }^{90} \mathrm{Sr}$ activity as the stage 1 aqueous sample taken after shutdown since the contactors were shutdown immediately after the 154 minute raffinate sample was taken. However, the ${ }^{90} \mathrm{Sr}$ activity of the stage 1 aqueous was much lower than the 154 minute sample $(282 \mathrm{dps} / \mathrm{mL}$ vs. $1420 \mathrm{dps} / \mathrm{mL})$. Therefore, it is likely that the raffinate sample taken at 154 minutes was contaminated and steady state was actually reached within 90 minutes.

\section{Concentrations at Shutdown}

The concentrations of ${ }^{90} \mathrm{Sr},{ }^{238} \mathrm{Pu},{ }^{235} \mathrm{U},{ }^{241} \mathrm{Am}, \mathrm{Pb}, \mathrm{H}^{+}, \mathrm{Na}, \mathrm{K}, \mathrm{Hg}$, and $\mathrm{Zr}$ in each stream immediately prior to shutdown are given in Figure 6. Material balances for ${ }^{90} \mathrm{Sr},{ }^{238} \mathrm{Pu},{ }^{235} \mathrm{U},{ }^{241} \mathrm{Am}$, total alpha, ${ }^{137} \mathrm{Cs}$, $\mathrm{Al}, \mathrm{Ba}, \mathrm{B}, \mathrm{Cd}, \mathrm{Ca}, \mathrm{Cr}, \mathrm{Fe}, \mathrm{Pb}, \mathrm{Mn}, \mathrm{Hg}, \mathrm{Ni}, \mathrm{Na}, \mathrm{K}$, and $\mathrm{Zr}$ are given in Table 7. The values in Table 7 were normalized to obtain an overall material balance of $100 \%$. Distribution coefficients were calculated for ${ }^{85} \mathrm{Sr}$, total alpha, $\mathrm{Pb}, \mathrm{Na}$, and $\mathrm{K}$ for several of the 24 stages. The resulting distribution coefficients are given in Table 8. A discussion of the behavior of each component follows. 


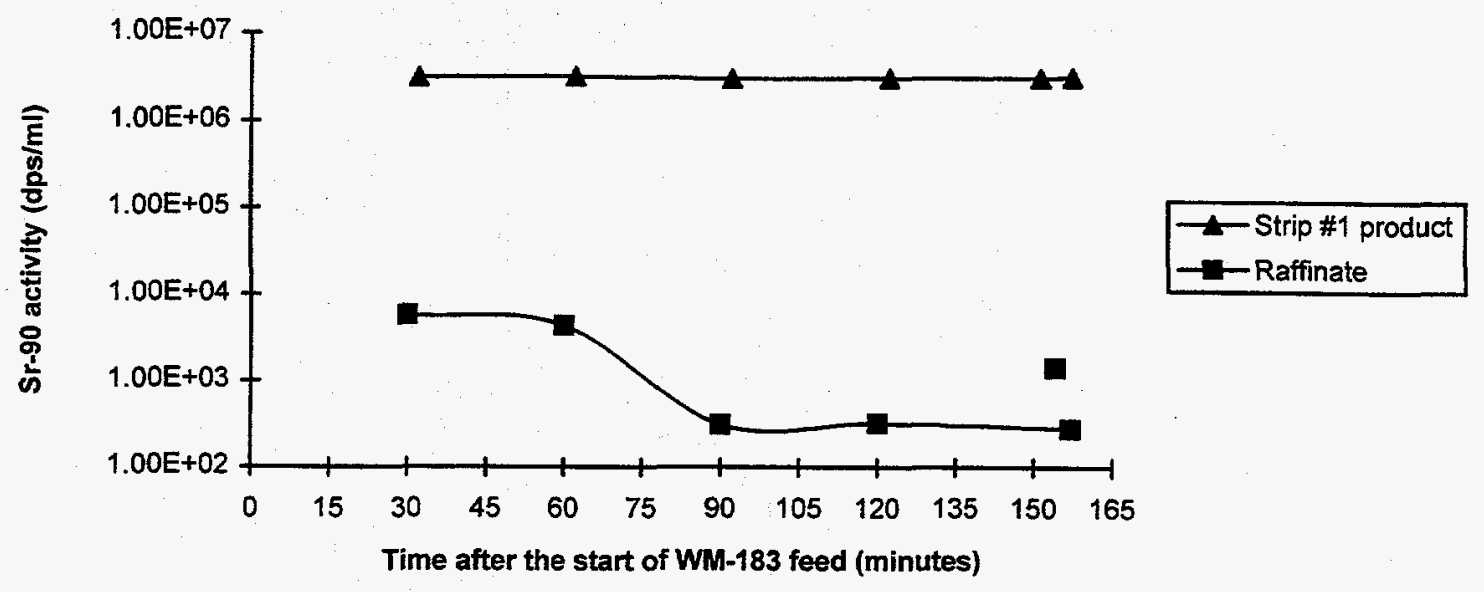

Figure 5. ${ }^{90} \mathrm{Sr}$ approach to steady state in the aqueous raffinate and strip \#1 product streams.

\begin{abstract}
${ }^{90}$ Strontium. The ${ }^{90} \mathrm{Sr}$ activity was reduced from $7.38 \mathrm{E}+06 \mathrm{dps} / \mathrm{mL}$ in the feed to $1.42 \mathrm{E}+03 \mathrm{dps} / \mathrm{mL}$ in the raffinate immediately prior to shutdown (154 minutes after the start of WM-183 feed). However, the activity of the raffinate 90 minutes and 120 minutes after the start of actual waste was $316 \mathrm{dps} / \mathrm{mL}$ and $326 \mathrm{dps} / \mathrm{mL}$, respectively. Also, the activity of the aqueous from stage 1 after the contactors were shutdown was $282 \mathrm{dps} / \mathrm{mL}$. The aqueous raffinate was sampled two minutes prior to shutdown so the stage 1 aqueous sample should have nearly the same ${ }^{90} \mathrm{Sr}$ activity as the raffinate sample. It is likely that the raffinate sample taken immediately prior to shutdown is not consistent with the other three raffinate samples due to contamination of the sample. Based on the activity of the 120 minute raffinate sample ( $326 \mathrm{dps} / \mathrm{mL}$ ), a removal efficiency of $99.995 \%$ was obtained for ${ }^{90} \mathrm{Sr}$. This corresponds to a ${ }^{90} \mathrm{Sr}$ activity of $0.0089 \mathrm{Ci} / \mathrm{m}^{3}$ which is below the NRC Class A LLW limit of $0.04 \mathrm{Ci} / \mathrm{m}^{3}$.
\end{abstract}

It is expected that the ${ }^{90} \mathrm{Sr}$ removal efficiency was limited in this test to $99.995 \%$ due to the presence of residual contamination in the centrifugal contactors. Testing of actinide separations flowsheets were performed in the contactors prior to this SREX testing. As a result, very high activities of ${ }^{90} \mathrm{Sr}$ were present in the contactors $(8.0 \mathrm{E}+06 \mathrm{dps} / \mathrm{mL})$, most notably in the stage one contactor which is nearest to the raffinate stream. The equipment was decontaminated remotely prior to this testing but small amounts . of contamination likely remained. Examination of the stage samples show that the activity of ${ }^{90} \mathrm{Sr}$ in the aqueous feed decreased substantially on each successive stage of the extraction section until stage 3 was reached. At this stage, the activity of ${ }^{90} \mathrm{Sr}$ leveled off at approximately $300 \mathrm{dps} / \mathrm{mL}$ (see Figure 7). It is expected that residual contamination from previous runs prevented the ${ }^{90} \mathrm{Sr}$ activity from continuing to drop on stages 3 through 1 . If the residual contamination had not been present, the activity of ${ }^{90} \mathrm{Sr}$ in the raffinate is expected to have been much lower than $326 \mathrm{dps} / \mathrm{mL}$.

Distribution coefficients in the extraction section ranged from 4.8 to 6.5 , which is higher than results from previous testing $\left(D_{\mathrm{Sr}}=2\right.$ to 3$){ }^{8,9}$ The higher distribution coefficients for this testing are attributed to the lower $\mathrm{Na}$ and $\mathrm{K}$ concentrations in the WM-183 waste as compared to the simulant used in previous testing, the slightly higher nitrate concentration of the WM-183 waste as compared to the simulant used previously ( $4.8 \mathrm{M}$ vs. $4.5 \mathrm{M})$, and the higher purity solvent used for this testing. 


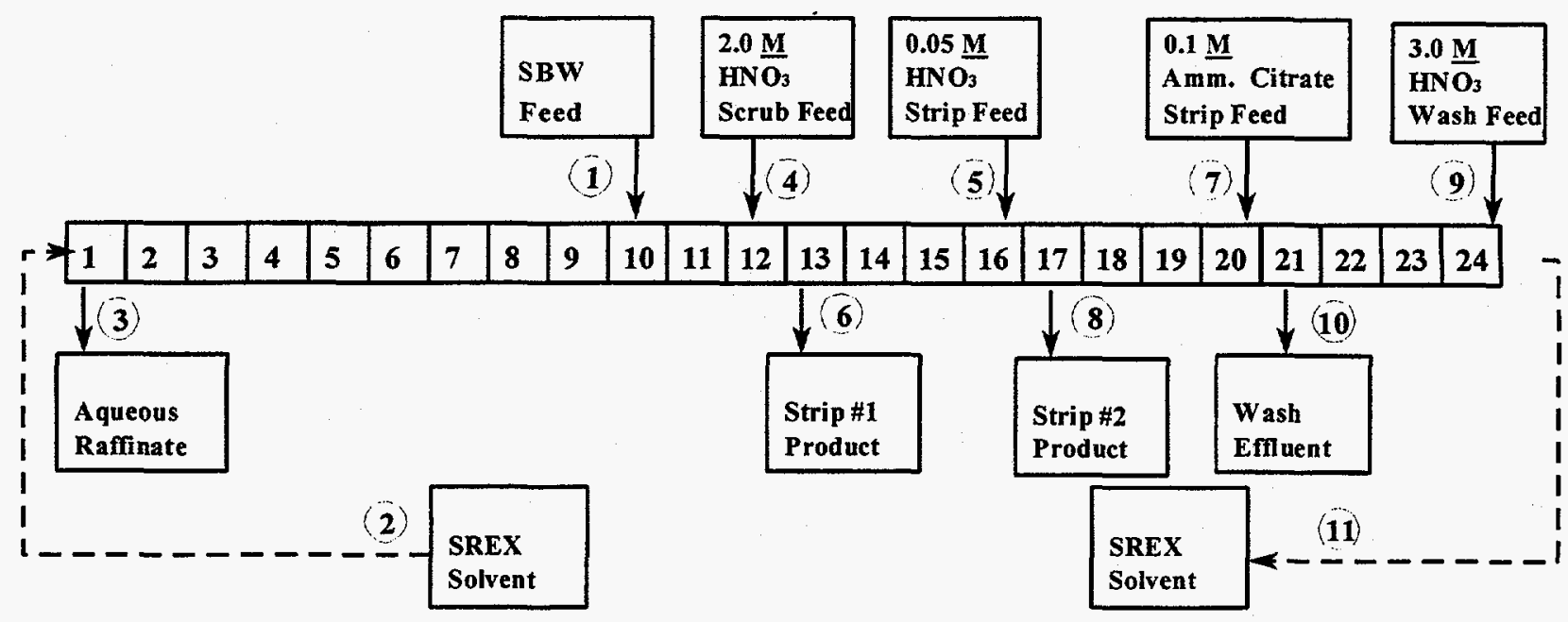

\begin{tabular}{|c|c|c|c|c|c|c|c|c|c|c|c|}
\hline Component & $\begin{array}{c}\text { SBW } \\
\text { Feed } \\
1\end{array}$ & $\begin{array}{c}\text { SREX } \\
\text { Solvent } \\
\text { Feed } \\
2\end{array}$ & $\begin{array}{c}\text { LAW } \\
\text { Raff. } \\
3\end{array}$ & $\begin{array}{c}\text { Scrub } \\
\text { Feed } \\
4\end{array}$ & $\begin{array}{c}\text { Strip \#1 } \\
\text { Feed } \\
5\end{array}$ & $\begin{array}{c}\text { Strip \#1 } \\
\text { Product } \\
6\end{array}$ & $\begin{array}{c}\text { Strip \#2 } \\
\text { Feed } \\
7\end{array}$ & $\begin{array}{c}\text { Strip \#2 } \\
\text { Product } \\
8\end{array}$ & $\begin{array}{c}\mathrm{HNO}_{3} \\
\text { Feed } \\
9\end{array}$ & $\begin{array}{c}\mathrm{HNO}_{3} \\
\text { Effluent } \\
10\end{array}$ & $\begin{array}{c}\text { SREX } \\
\text { Solvent } \\
\text { Effluent } \\
11\end{array}$ \\
\hline $\mathrm{H}^{+}(M)$ & 1.77 & -- & 1.98 & 2.0 & 0.05 & 0.51 & -- & -- & 3.0 & 1.08 & - \\
\hline Amm. citrate $(M)$ & --- & -- & - & -- & -- & $\cdots$ & 0.1 & 0.1 & --- & -- & -- \\
\hline${ }^{90} \mathrm{Sr}(\mathrm{dps} / \mathrm{mL})$ & $7.38 \mathrm{E}+06$ & --- & 326 & -- & -- & $3.10 \mathrm{E}+06$ & -- & 435 & -- & 58 & 4.6 \\
\hline $238 \mathrm{Pu}(\mathrm{dps} / \mathrm{mL})$ & $1.53 \mathrm{E}+04$ & - & 6.30 & -- & -- & 52.8 & - & $1.02 E \div 04$ & -- & 2.17 & 7.34 \\
\hline${ }^{241} \mathrm{Am}(\mathrm{dps} / \mathrm{mL})$ & $1.60 \mathrm{E}+03$ & - & $1.22 \mathrm{E}+03$ & -- & -- & 4.08 & --- & 13.0 & -- & 5.23 & 0.06 \\
\hline $238 \mathrm{U}(\mathrm{mg} / \mathrm{L})$ & 111 & - & 0.23 & -- & --- & 37.1 & -- & 12.2 & -- & --- & 0.012 \\
\hline $\mathrm{Pb}(M)$ & $1.12 \mathrm{E}-03$ & - & $<2.6 \mathrm{E}-05$ & - & -- & $<2.6 \mathrm{E}-05$ & - & $8.0 \mathrm{E}-04$ & - & $<2.6 \mathrm{E}-05$ & $<1.3 \mathrm{E}-06$ \\
\hline $\mathrm{Na}(M)$ & 0.68 & -- & 0.47 & - & - & $<5.2 \mathrm{E}-05$ & -- & $9.00 \mathrm{E}-04$ & -- & $2.40 \mathrm{E}-03$ & $1.95 \mathrm{E}-04$ \\
\hline $\mathrm{K}(M)$ & 0.094 & -- & 0.048 & $\cdots$ & -- & 0.014 & - & $4.07 \mathrm{E}-04$ & -- & $<3.5 \mathrm{E}-04$ & 2.07E-05 \\
\hline $\mathrm{Hg}(M)$ & 0.0013 & -- & $<1.9 \mathrm{E}-04$ & -- & -- & $<1.9 \mathrm{E}-04$ & - & $<1.9 \mathrm{E}-04$ & -- & $<1.9 \mathrm{E}-04$ & -- \\
\hline $\operatorname{Zr}(M)$ & 4.2E-04 & --- & $<5.7 \mathrm{E}-05$ & -- & -- & $8.10 \mathrm{E}-05$ & --- & $<5.7 \mathrm{E}-05$ & -- & $<1.2 \mathrm{E}-04$ & $<1.4 \mathrm{E}-06$ \\
\hline Flowrate $(\mathrm{mL} / \mathrm{min})$ & 5.8 & 8.2 & 7.8 & 2.0 & 15.1 & 15.1 & 7.9 & 7.9 & 4.0 & 4.0 & 8.2 \\
\hline
\end{tabular}

Figure 6. Steady state concentrations for SREX flowsheet testing with WM-183 tank waste. 
Table 7. Percentage of component in each of the effluent streams for SREX flowsheet testing with WM-183 tank waste.

\begin{tabular}{|c|c|c|c|c|c|c|}
\hline Stream & ${ }^{90} \mathrm{Sr}$ & Alpha & ${ }^{241} \mathrm{Am}$ & ${ }^{137} \mathrm{Cs}$ & ${ }^{238} \mathrm{Pu}$ & ${ }^{239} \mathrm{Pu}$ \\
\hline $\begin{array}{l}\text { Aqueous } \\
\text { Raffinate }\end{array}$ & $\begin{array}{c}0.006 \% \\
(0.005 \%)^{a}\end{array}$ & $\begin{array}{c}6.09 \% \\
(6.01 \%)\end{array}$ & $\begin{array}{l}102.5 \% \\
(98.1 \%)\end{array}$ & $\begin{array}{l}104.6 \% \\
(99.6 \%)\end{array}$ & $\begin{array}{c}0.055 \% \\
(0.060 \%)\end{array}$ & $\begin{array}{c}0.028 \% \\
(0.027 \%)\end{array}$ \\
\hline $\begin{array}{l}\text { Strip \#1 } \\
\text { Product }\end{array}$ & $\begin{array}{c}108.8 \% \\
(99.99 \%)\end{array}$ & $\begin{array}{c}5.51 \% \\
(5.44 \%)\end{array}$ & $\begin{array}{c}0.66 \% \\
(0.63 \%)\end{array}$ & $\begin{array}{c}0.013 \% \\
(0.012 \%)\end{array}$ & $\begin{array}{c}0.89 \% \\
(0.98 \%)\end{array}$ & $\begin{array}{c}8.80 \% \\
(8.74 \%)\end{array}$ \\
\hline $\begin{array}{l}\text { Strip \#2 } \\
\text { Product }\end{array}$ & $\begin{array}{c}0.008 \% \\
(0.007 \%)\end{array}$ & $\begin{array}{c}89.6 \% \\
(88.4 \%)\end{array}$ & $\begin{array}{c}1.1 \% \\
(1.1 \%)\end{array}$ & $\begin{array}{c}0.19 \% \\
(0.18 \%)\end{array}$ & $\begin{array}{c}90.6 \% \\
(98.9 \%)\end{array}$ & $\begin{array}{c}91.8 \% \\
(91.2 \%)\end{array}$ \\
\hline $\begin{array}{l}\mathrm{HNO}_{3} \\
\text { Effluent }\end{array}$ & $\begin{array}{c}0.0005 \% \\
(0.0005 \%)\end{array}$ & $\begin{array}{c}0.024 \% \\
(0.024 \%)\end{array}$ & $\begin{array}{c}0.22 \% \\
(0.21 \%)\end{array}$ & $\begin{array}{c}0.24 \% \\
(0.22 \%)\end{array}$ & $\begin{array}{c}0.0097 \% \\
(0.010 \%)\end{array}$ & $\begin{array}{c}0.0064 \% \\
(0.0064 \%)\end{array}$ \\
\hline $\begin{array}{l}\text { Solvent } \\
\text { Effluent }\end{array}$ & $\begin{array}{c}0.00009 \% \\
(0.00008 \%)\end{array}$ & $\begin{array}{c}0.083 \% \\
(0.082 \%)\end{array}$ & $\begin{array}{c}0.006 \% \\
(0.005 \%)\end{array}$ & $\begin{array}{c}0.0007 \% \\
(0.0007 \%)\end{array}$ & $\begin{array}{c}0.067 \% \\
(0.073 \%)\end{array}$ & $\begin{array}{c}0.059 \% \\
(0.059 \%)\end{array}$ \\
\hline Mass Balance $^{\mathrm{b}}$ & $108.8 \%$ & $101.3 \%$ & $104.5 \%$ & $105.1 \%$ & $91.6 \%$ & $100.7 \%$ \\
\hline Stream & ${ }^{235} \mathrm{U}$ & ${ }^{238} \mathrm{U}$ & Al & $\mathrm{Ba}$ & B & $\mathrm{Cd}$ \\
\hline $\begin{array}{l}\text { Aqueous } \\
\text { Raffinate }\end{array}$ & $\begin{array}{c}0.41 \% \\
(0.42 \%)\end{array}$ & $\begin{array}{c}0.28 \% \\
(0.28 \%)\end{array}$ & $\begin{array}{c}94.7 \% \\
(99.2 \%)\end{array}$ & $36.4 \%$ & $95.5 \%$ & $100.6 \%$ \\
\hline $\begin{array}{l}\text { Strip \#1 } \\
\text { Product }\end{array}$ & $\begin{array}{c}86.3 \% \\
(88.9 \%)\end{array}$ & $\begin{array}{c}86.6 \% \\
(85.0 \%)\end{array}$ & $\begin{array}{c}<0.31 \% \\
(<0.32 \%)\end{array}$ & $130.2 \%$ & $<10.8 \%$ & $6.2 \%$ \\
\hline $\begin{array}{l}\text { Strip \#2 } \\
\text { Product }\end{array}$ & $\begin{array}{c}10.4 \% \\
(10.7 \%)\end{array}$ & $\begin{array}{c}14.9 \% \\
(14.7 \%)\end{array}$ & $\begin{array}{c}0.18 \% \\
(0.19 \%)\end{array}$ & $<16.3 \%$ & $<5.7 \%$ & $<1.2 \%$ \\
\hline $\begin{array}{l}\mathrm{HNO}_{3} \\
\text { Effluent }\end{array}$ & -- & --- & $\begin{array}{c}0.23 \% \\
(0.24 \%)\end{array}$ & $<17.8 \%$ & $<6.2 \%$ & $<1.2 \%$ \\
\hline $\begin{array}{l}\text { Solvent } \\
\text { Effluent }\end{array}$ & $\begin{array}{c}0.014 \% \\
(0.014 \%)\end{array}$ & $\begin{array}{c}0.015 \% \\
(0.015 \%)\end{array}$ & $\begin{array}{c}0.013 \% \\
(0.014 \%)\end{array}$ & $0.76 \%$ & $3.2 \%$ & $<0.03 \%$ \\
\hline Mass Balance $^{\mathrm{b}}$ & $97.1 \%$ & $101.8 \%$ & $95.4 \%$ & $167 \%-201 \%$ & $99 \%-121 \%$ & $107 \%-109 \%$ \\
\hline
\end{tabular}


Table 7 (continued). Percentage of component in each of the effluent streams for SREX flowsheet testing with WM-183 tank waste.

\begin{tabular}{|c|c|c|c|c|c|}
\hline Stream & $\mathrm{Ca}$ & $\mathrm{Cr}$ & $\mathrm{Fe}$ & $\mathrm{Pb}$ & $\mathrm{Mn}$ \\
\hline $\begin{array}{l}\text { Aqueous } \\
\text { Raffinate }\end{array}$ & $\begin{array}{c}93.9 \% \\
(95.1 \%)^{a}\end{array}$ & $97.1 \%$ & $\begin{array}{c}97.8 \% \\
(98.3 \%)\end{array}$ & $<6.0 \%$ & $\begin{array}{c}95.0 \% \\
(99.6 \%)\end{array}$ \\
\hline $\begin{array}{l}\text { Strip \#1 } \\
\text { Product }\end{array}$ & $\begin{array}{c}2.3 \% \\
(2.3 \%)\end{array}$ & $<0.9 \%$ & $\begin{array}{c}1.0 \% \\
(1.0 \%)\end{array}$ & $<11.5 \%$ & $\begin{array}{c}0.16 \% \\
(0.17 \%)\end{array}$ \\
\hline $\begin{array}{l}\text { Strip \#2 } \\
\text { Product }\end{array}$ & $\begin{array}{c}1.6 \% \\
(1.6 \%)\end{array}$ & $<0.5 \%$ & $\begin{array}{c}0.30 \% \\
(0.30 \%)\end{array}$ & $93.2 \%$ & $\begin{array}{c}<0.08 \% \\
(<0.09 \%)\end{array}$ \\
\hline $\begin{array}{l}\mathrm{HNO}_{3} \\
\text { Effluent }\end{array}$ & $\begin{array}{c}0.90 \% \\
(0.92 \%)\end{array}$ & $<0.5 \%$ & $\begin{array}{c}0.36 \% \\
(0.36 \%)\end{array}$ & $<1.5 \%$ & $\begin{array}{c}0.14 \% \\
(0.15 \%)\end{array}$ \\
\hline $\begin{array}{l}\text { Solvent } \\
\text { Effluent }\end{array}$ & $\begin{array}{c}0.071 \% \\
(0.072 \%)\end{array}$ & $0.02 \%$ & $\begin{array}{c}0.0028 \% \\
(0.0028 \%)\end{array}$ & $<0.16 \%$ & $\begin{array}{l}<0.002 \% \\
(<0.002 \%)\end{array}$ \\
\hline Mass Balance ${ }^{b}$ & $98.7 \%$ & $97 \%-99 \%$ & $99.5 \%$ & $93 \%-112 \%$ & $95.3 \%$ \\
\hline Stream & $\mathrm{Hg}$ & $\mathrm{Ni}$ & $\mathrm{Na}$ & $\mathrm{K}$ & $\mathrm{Zr}$ \\
\hline $\begin{array}{l}\text { Aqueous } \\
\text { Raffinate }\end{array}$ & $<10.8 \%$ & $106.8 \%$ & $\begin{array}{c}93.4 \% \\
(99.5 \%)\end{array}$ & $\begin{array}{c}68.5 \% \\
(62.8 \%)\end{array}$ & $<18.4 \%$ \\
\hline $\begin{array}{l}\text { Strip \#1 } \\
\text { Product }\end{array}$ & $<2.7 \%$ & $<3.2 \%$ & $\begin{array}{c}<0.02 \% \\
(<0.02 \%)\end{array}$ & $\begin{array}{c}39.7 \% \\
(36.4 \%)\end{array}$ & $50.3 \%$ \\
\hline $\begin{array}{l}\text { Strip \#2 } \\
\text { Product }\end{array}$ & $<1.4 \%$ & $<1.7 \%$ & $\begin{array}{c}0.18 \% \\
(0.19 \%)\end{array}$ & $\begin{array}{c}0.59 \% \\
(0.54 \%)\end{array}$ & $<18.6 \%$ \\
\hline $\begin{array}{l}\mathrm{HNO}_{3} \\
\text { Effluent }\end{array}$ & $<0.7 \%$ & $<1.8 \%$ & $\begin{array}{c}0.24 \% \\
(0.26 \%)\end{array}$ & $\begin{array}{c}0.25 \% \\
(0.23 \%)\end{array}$ & $<20.3 \%$ \\
\hline $\begin{array}{l}\text { Solvent } \\
\text { Effluent }\end{array}$ & -- & $<0.04 \%$ & $\begin{array}{c}0.040 \% \\
(0.043 \%)\end{array}$ & $\begin{array}{c}0.031 \% \\
(0.028 \%)\end{array}$ & $<0.48 \%$ \\
\hline Mass Balance $^{b}$ & --- & $107 \%-113 \%$ & $93.8 \%$ & $109.0 \%$ & $50 \%-108 \%$ \\
\hline
\end{tabular}


Table 8. ${ }^{90} \mathrm{Sr}$, total alpha, $\mathrm{Pb}, \mathrm{Na}$, and $\mathrm{K}$ distribution coefficients for SREX flowsheet testing with WM-183 tank waste.

\begin{tabular}{cclllll}
\hline \multirow{2}{*}{ Section } & Stage & $\mathrm{D}_{\mathrm{Sr}}$ & $\mathrm{D}_{\text {alpha }}$ & $\mathrm{D}_{\mathrm{Pb}}$ & $\mathrm{D}_{\mathrm{Na}}$ & $\mathrm{D}_{\mathrm{K}}$ \\
\hline \multirow{2}{*}{ Extraction } & 1 & $\mathrm{nd}^{\mathrm{a}}$ & $\mathrm{nd}$ & $\mathrm{nd}$ & nd & nd \\
& 3 & nd & nd & nd & nd & nd \\
& 5 & 6.1 & 0.21 & $>1.5$ & 0.091 & 0.69 \\
& 6 & 4.8 & nd & nd & nd & nd \\
& 7 & 6.3 & 0.18 & $>2.5$ & 0.087 & 0.72 \\
& 9 & 6.5 & nd & nd & nd & nd \\
Scrub & 10 & 6.1 & 8.5 & $>22$ & 0.089 & 0.69 \\
& 11 & 5.8 & 23.3 & $>38$ & 0.23 & 0.84 \\
Strip \#1 & 12 & 5.7 & 51.5 & $>38$ & 13.2 & 1.3 \\
& 13 & 1.1 & 15.9 & $>50$ & nd & nd \\
Strip \#2 & 16 & 0.08 & 7.2 & 9.4 & $>8.1$ & 0.85 \\
& 17 & 0.01 & 0.018 & $<6.4 \mathrm{E}-4$ & $>7.0$ & 0.3 \\
Acidification & 20 & 0.34 & 0.032 & nd & $>1.1$ & 0.15 \\
\hline \multirow{2}{*}{ a. Not determined. } & 22 & 0.21 & 3.97 & nd & $>6.1$ & 0.26 \\
\hline
\end{tabular}

The $0.05 M$ nitric acid strip section was very effective in back-extracting the ${ }^{90} \mathrm{Sr}$ from the SREX solvent, resulting in $99.999 \%$ of the extracted ${ }^{90} \mathrm{Sr}$ being stripped from the SREX solvent with the four strip stages. As a result, $0.007 \%$ of the ${ }^{90} \mathrm{Sr}$ in the feed exited with the strip $\# 2$ product ( $\mathrm{Pb}$ strip).

Experimental distribution coefficients obtained for ${ }^{90} \mathrm{Sr}$ were used in conjunction with the Generic TRUEX Model (GTM) in order to determine the operating efficiency of the contactors during testing. ${ }^{10}$ The best fit of the GTM data to the experimental data was obtained at an operating efficiency of $91 \%$ in the extraction section and $99 \%$ in the remaining sections. An other-phase carryover of $0.5 \%$ was assumed for each stage. The predicted ${ }^{90} \mathrm{Sr}$ activities are compared to the experimental activities in Figures 7 and 8 . Note that the ${ }^{90} \mathrm{Sr}$ activity in the aqueous phase begins to deviate from the GTM predicted activities on stage 5 and does not continue to decrease on stages 1 through 3 . This is believed to be due to the residual activity in the contactors from previous testing. Without the contamination in the contactors, the GTM predicts the ${ }^{90} \mathrm{Sr}$ activity in the raffinate would have been approximately two orders of magnitude lower than were obtained with this testing $(3 \mathrm{dps} / \mathrm{mL})$. The same contamination from residual activity is also apparent from the aqueous and organic samples on stages 17 through 24 . Activities of these samples also level off, while the GTM predicts much lower activities.

It is possible that the activity of ${ }^{90} \mathrm{Sr}$ levels off on the early stages of the extraction section due to the formation of inextractable $\mathrm{Sr}$ complexes. In order to verify that this is not the case, the raffinate sample was contacted twice with equal volumes of the SREX solvent. After each contact, a sample of the aqueous phase was analyzed for ${ }^{90} \mathrm{Sr}$. The activity of ${ }^{90} \mathrm{Sr}$ decreased from $1420 \mathrm{dps} / \mathrm{mL}$ to $469 \mathrm{dps} / \mathrm{ml}$ after the first contact and to $126 \mathrm{dps} / \mathrm{mL}$ after the second contact. If the formation of inextractable $\mathrm{Sr}$ complexes was the explanation for the activity of ${ }^{90} \mathrm{Sr}$ leveling off in the extraction section, the ${ }^{90} \mathrm{Sr}$ activities would not have decreased with the second contact. 


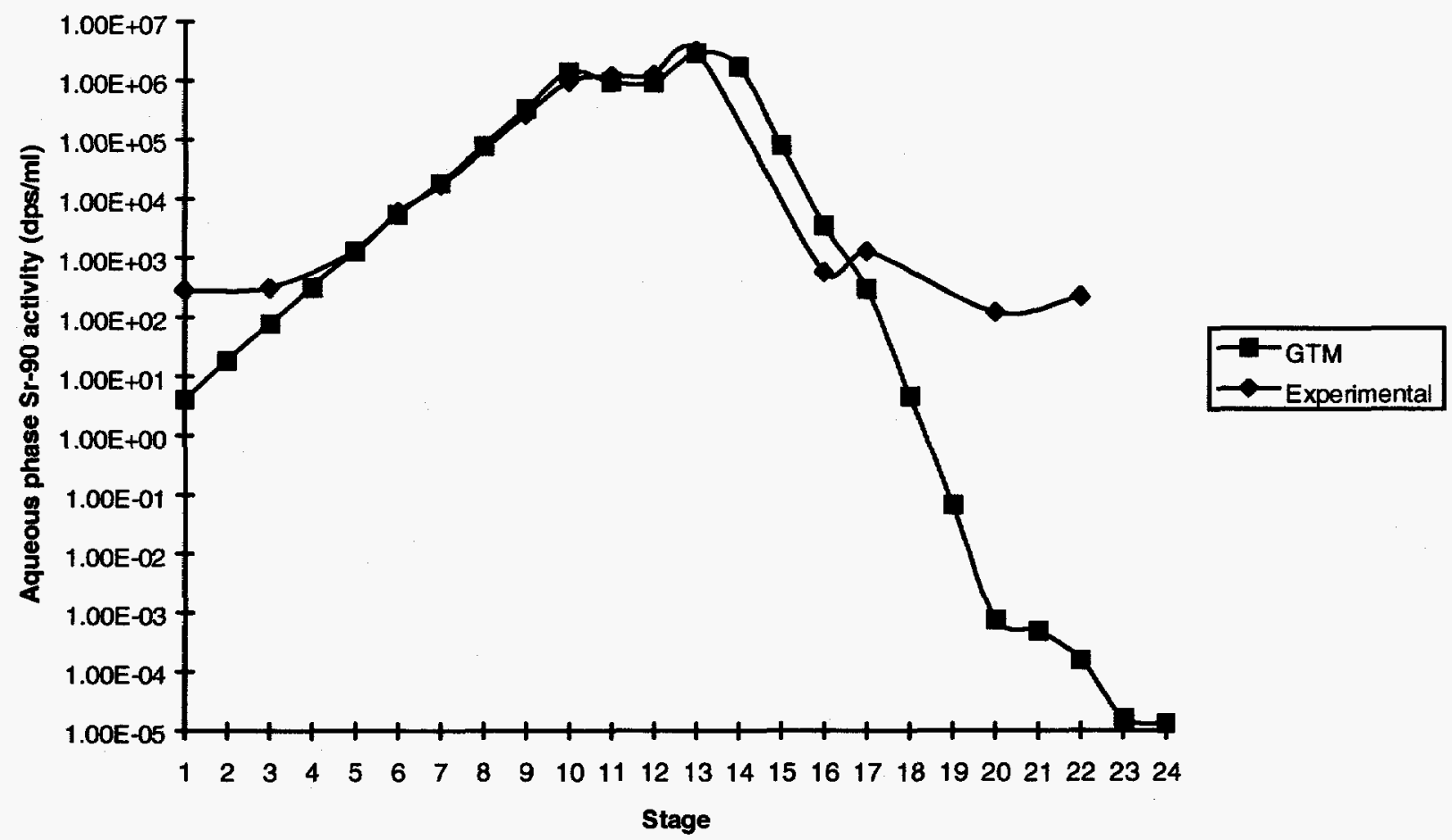

Figure 7. Comparison of experimental results with Generic TRUEX Model results (aqueous phase stage compositions).

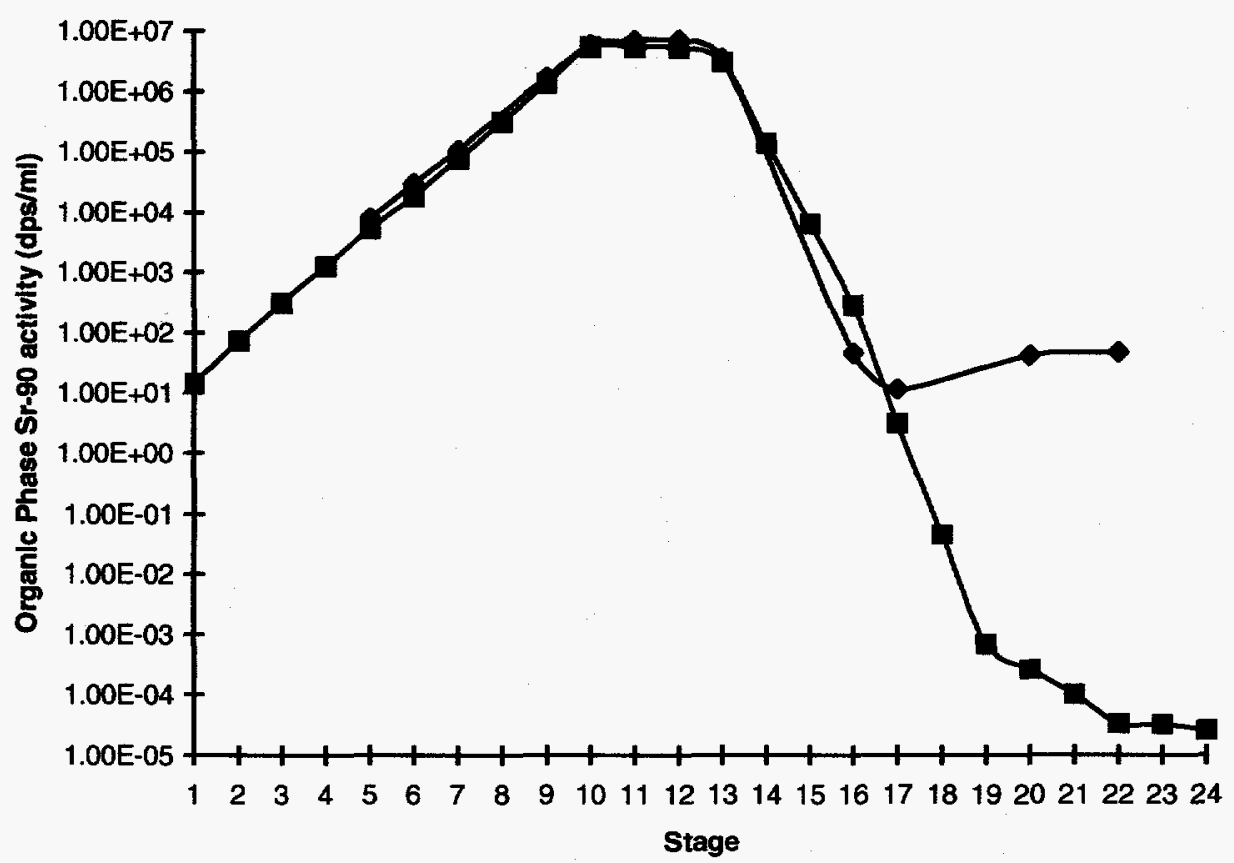

Figure 8. Comparison of experimental results with Generic TRUEX Model results (organic phase stage compositions). 
Lead. The SREX solvent extracted $>94 \%$ of the $\mathrm{Pb}$ from the SBW simulant. Analytical detection limits for $\mathrm{Pb}$ in the aqueous raffinate were reached so the actual $\mathrm{Pb}$ removal efficiency could not be determined. However, $\mathrm{Pb}$ distribution coefficients in the extraction section ranged from $>1.5$ to $>22$ indicating that $>99.9 \%$ of the $\mathrm{Pb}$ was extracted. The first strip section $\left(0.05 M \mathrm{HNO}_{3}\right)$ back-extracted $<11.5 \%$ of the $\mathrm{Pb}$ from the SREX solvent. The ammonium nitrate strip section effectively back-extracted the remaining $\mathrm{Pb}$. Based on previous flowsheet testing, ${ }^{9}$ it was expected that less than $2 \%$ of the $\mathrm{Pb}$ would exit with the strip \#1 product. A lower detection limit was obtained for the stage 11 aqueous sample, indicating that $<6 \%$ of the $\mathrm{Pb}$ exited with the strip \#1 product. Using the distribution coefficients obtained for $\mathrm{Pb}$ in the strip sections ( $\mathrm{D}_{\mathrm{Pb}}>50$ on stage 11 and $\mathrm{D}_{\mathrm{Pb}}=9.4$ on stage 16 ), the GTM predicts $<4 \%$ of the $\mathrm{Pb}$ exited with the strip \#1 product.

Other non-radioactive elements. $\mathrm{Hg}, \mathrm{K}, \mathrm{Ba}$, and $\mathrm{Zr}$ were extracted from the $\mathrm{SBW}(>89.2 \%$ of the $\mathrm{Hg}, 32.5 \%$ of the $\mathrm{K}, 63.6 \%$ of the $\mathrm{Ba}$, and $>81.6 \%$ of the $\mathrm{Zr}$ ). Of these components, only $\mathrm{Hg}$ was not effectively stripped from the SREX solvent. Less than $5 \%$ of the $\mathrm{Hg}$ was stripped from the solvent with the two strip sections. The remaining $\mathrm{Hg}$ exited with the solvent effluent. The extraction of $\mathrm{Hg}$ is less of a concern if the SREX process follows the TRUEX process because the TRUEX process will extract $75 \%$ to $95 \%$ of the $\mathrm{Hg}$ from the waste. ${ }^{11}$ Very little of the $\mathrm{K}$ was scrubbed from the SREX solvent with the $2 \mathrm{MHNO}_{3}$. Distribution coefficients for $\mathrm{K}$ in the scrub section were 0.84 and 1.3 . The $\mathrm{K}$ was effectively stripped from the SREX solvent with the $0.05 M \mathrm{HNO}_{3}$ strip section. $\mathrm{Al}, \mathrm{B}, \mathrm{Cd}, \mathrm{Ca}, \mathrm{Cs}, \mathrm{Cr}$, $\mathrm{Fe}, \mathrm{Mn}$, and $\mathrm{Ni}$ were determined to be essentially inextractable.

Actinides. The SREX solvent consists of $0.15 M 4^{\prime}, 4^{\prime}\left(5^{\prime}\right)$-di-(tert-butyldicyclohexo)-18-crown-6 and $1.5 \mathrm{M}$ tributyl phosphate in an Isopar- $\mathrm{L}^{\circledast}$ diluent. The $1.5 \mathrm{M}$ tributyl phosphate in an Isopar- $\mathrm{L}^{\circledR}$ diluent is very similar to the PUREX solvent and, therefore, is expected to extract uranium and plutonium, but not americium, from the SBW. Removal efficiencies of $99.94 \%, 99.97 \%, 99.6 \%$, and $99.7 \%$ were obtained for ${ }^{238} \mathrm{Pu},{ }^{239} \mathrm{Pu},{ }^{235} \mathrm{U}$, and ${ }^{238} \mathrm{U}$, respectively. However, only $2 \%$ of the ${ }^{241} \mathrm{Am}$ was extracted from the SBW. As a result, the total alpha activity was reduced from $506 \mathrm{nCi} / \mathrm{g}$ in the $\mathrm{SBW}$ feed to $23 \mathrm{nCi} / \mathrm{g}$ in the raffinate, which corresponds to the activity of ${ }^{241} \mathrm{Am}$ in the SBW feed $(35 \mathrm{nCi} / \mathrm{g})$. Therefore, the alpha activity can only be reduced with the SREX process to approximately $25 \mathrm{nCi} / \mathrm{g}$, which is below the NRC Class B and Class C limit of $100 \mathrm{nCi} / \mathrm{g}$ for non-TRU waste but above the NRC Class A limit of 10 $\mathrm{nCi} / \mathrm{g}$.

The $0.05 \mathrm{MHNO}_{3}$ strip section removed approximately $87 \%$ of the $\mathrm{U}$ from the SREX solvent. However, very little of the Pu was stripped $(<10 \%)$. The ammonium citrate strip section effectively back-extracted the remaining $\mathrm{Pu}$ and $\mathrm{U}$ from the solvent. Subsequent laboratory studies have indicated that impurities and degradation products present in the tributyl phosphate will prevent the Pu from stripping with dilute $\mathrm{HNO}_{3}{ }^{6}$ Washing the solvent with $0.25 \mathrm{MNa}_{2} \mathrm{CO}_{3}$ will remove the degradation products and allow the Pu to be effectively stripped with $0.05 M \mathrm{HNO}_{3}$. The SREX flowsheet testing was performed using SREX solvent which had not been washed with $\mathrm{Na}_{2} \mathrm{CO}_{3}$, resulting in the ineffective stripping of $\mathrm{Pu}$ with $0.05 \mathrm{MHNO}_{3}$.

\section{Comparison of Laboratory and Pilot Plant Results}

Results of the flowsheet testing with spiked SBW simulant, flowsheet testing with WM-183 waste, and laboratory batch contact flowsheet tests ${ }^{6}$ are compared in Tables 9 and 10 . Table 9 gives the percentage of each component extracted in the flowsheet tests. Table 10 gives the distribution coefficients of $\mathrm{Sr}$ and $\mathrm{Pb}$ in the extraction, scrub, strip \#1 and strip \#2 sections. Results from each test are very comparable, indicating that testing with simulated waste is representative of actual conditions. 
Table 9. Comparison of removal efficiencies for flowsheet testing with spiked simulant and WM-183.

\begin{tabular}{ccc}
\hline & & Removal Efficiency \\
Component & Simulant & WM-183 \\
\hline $\mathrm{Sr}$ & $>99.96 \%$ & $99.995 \%$ \\
$\mathrm{~Pb}$ & $>99.97 \%$ & $>94 \%$ \\
$\mathrm{Hg}$ & $99.992 \%$ & $>89 \%$ \\
$\mathrm{Na}$ & $0.1 \%$ & $0.5 \%$ \\
$\mathrm{~K}$ & $39.1 \%$ & $37.2 \%$ \\
\hline
\end{tabular}

Table 10. Comparison of distribution coefficients from flowsheet testing and laboratory testing.

\begin{tabular}{|c|c|c|c|c|c|c|}
\hline \multirow[b]{2}{*}{ Section } & \multicolumn{3}{|c|}{$D_{\mathrm{Sr}}$} & \multicolumn{3}{|c|}{$\mathbf{D}_{\mathbf{P b}}$} \\
\hline & $\begin{array}{c}\text { Batch } \\
\text { Contacts }\end{array}$ & $\begin{array}{l}\text { Contactor } \\
\text { Test with } \\
\text { Simulant }\end{array}$ & $\begin{array}{l}\text { Contactor } \\
\text { Test with } \\
\text { WM-183 }\end{array}$ & $\begin{array}{c}\text { Batch } \\
\text { Contacts }\end{array}$ & $\begin{array}{l}\text { Contactor } \\
\text { Test with } \\
\text { Simulant }\end{array}$ & $\begin{array}{l}\text { Contactor } \\
\text { Test with } \\
\text { WM-183 }\end{array}$ \\
\hline Extraction & 5.3 to 6.3 & $>4.1$ to 8.1 & 4.8 to 6.5 & 100 to 158 & $>466$ & $>1.5$ to $>22$ \\
\hline Scrub & 4.4 to 4.5 & 6.0 to 7.0 & 5.7 to 5.8 & -- & 46 & $>38$ \\
\hline Strip \#1 & 0.1 to 0.4 & $<0.05$ to 1.0 & 0.08 to 1.1 & 5.5 to 79 & -- & 9.4 to $>50$ \\
\hline Strip \#2 & --- & --- & 0.01 to 0.34 & 0.4 & $\ldots$ & $<6.4 \mathrm{E}-04$ \\
\hline
\end{tabular}




\section{CONCLUSIONS AND RECOMMENDATIONS}

\section{Conclusions}

Lead and strontium were extracted and selectively stripped from the SBW simulant and the actual waste from tank WM-183. For the testing with actual waste from tank WM-183, removal efficiencies of $99.995 \%$ and $>94 \%$ were obtained for ${ }^{90} \mathrm{Sr}$ and $\mathrm{Pb}$, respectively. With this removal efficiency for ${ }^{90} \mathrm{Sr}$, the activity of ${ }^{90} \mathrm{Sr}$ was reduced to $0.0089 \mathrm{Ci} / \mathrm{m}^{3}$ which is below the NRC Class A LLW limit of 0.04 $\mathrm{Ci} / \mathrm{m}^{3}$ for ${ }^{90} \mathrm{Sr}$. It is expected that even further ${ }^{90} \mathrm{Sr}$ decontamination would have been obtained if the centrifugal contactors used for testing did not contain residual contamination from previous actinide flowsheet development work.

For the testing with actual waste from tank WM-183, $99.99 \%$ of the extracted ${ }^{90} \mathrm{Sr}$ and $<6 \%$ of the extracted $\mathrm{Pb}$ exited with the $0.05 \mathrm{M}$ nitric acid strip product. $0.007 \%$ of the ${ }^{90} \mathrm{Sr}$ and $93 \%$ of the $\mathrm{Pb}$ exited with the $0.1 \mathrm{M}$ ammonium citrate strip product.

The SREX flowsheet separated $94 \%$ of the total alpha activity from the WM- 183 waste. This high removal efficiency is due to the nearly complete extraction of $\mathrm{Pu}(99.94 \%)$ and $\mathrm{U}(99.6 \%)$ by the tributyl phosphate in the SREX solvent. However, only $1.9 \%$ of the ${ }^{241} \mathrm{Am}$ was extracted. Since ${ }^{241} \mathrm{Am}$ accounts for approximately $6 \%$ of the total alpha activity in the WM-183 waste, the alpha activity can only be reduced with the SREX process to approximately $25 \mathrm{nCi} / \mathrm{g}$, which is below the $\mathrm{NRC}$ Class $\mathrm{B}$ and $\mathrm{C}$ limit of $100 \mathrm{nCi} / \mathrm{g}$ for non-TRU waste but above the NRC Class A limit of $10 \mathrm{nCi} / \mathrm{g}$.

$\mathrm{Pu}$ was not effectively stripped from the SREX solvent with $0.05 M \mathrm{HNO}_{3}$ due to the impurities and degradation products present in the unwashed SREX solvent. However, the $0.1 \mathrm{M}$ ammonium citrate stripped the remaining $\mathrm{Pu}$ from the solvent.

For the testing with actual waste from tank WM-183, $37.2 \%$ of the $\mathrm{K},>89 \%$ of the $\mathrm{Hg}, 0.5 \%$ of the $\mathrm{Na},>81.6 \%$ of the $\mathrm{Zr}$, and $64 \%$ of the $\mathrm{Ba}$ were extracted by the SREX solvent. Of these components, only $\mathrm{Hg}$ was not effectively stripped from the SREX solvent. $\mathrm{Al}, \mathrm{B}, \mathrm{Cd}, \mathrm{Ca}, \mathrm{Cs}, \mathrm{Cr}, \mathrm{Fe}, \mathrm{Mn}$, and $\mathrm{Ni}$ were determined to be essentially inextractable.

Flooding, precipitation, and/or third phase formation were not observed during testing with simulated SBW or actual waste from tank WM-183.

The operational efficiency of the centrifugal contactors for the flowsheet testing with WM-183 was calculated to be approximately $91 \%$ for the extraction section.

Results obtained from the flowsheet test with actual tank waste were very consistent with results from laboratory testing and flowsheet testing with simulated waste solution. The SBW simulant is an effective surrogate for the actual tank waste. 


\section{Recommendations}

The SREX process for the separation of strontium from ICPP SBW is now sufficiently developed to allow transfer of the technology from the EM-50 Tanks Focus Area to EM-30.

The SREX flowsheet tested should be used as a basis for feasibility studies and/or facility design studies.

An evaluation should be performed to determine if the extraction of $K$ by the SREX solvent would have an adverse effect on the quantity or quality of HLW glass. If it does, an alternative scrub solution should be developed and tested for the scrubbing of $\mathrm{K}$ from the solvent.

A strip solution should be developed for the back-extraction of $\mathrm{Hg}$ from the SREX solvent. The ability to strip $\mathrm{Hg}$ will be a contributing factor in the determination of the sequence of the separations processes.

The SREX solvent should be washed with $0.25 \mathrm{MNa}_{2} \mathrm{CO}_{3}$ prior to performing flowsheet testing in order to remove impurities and degradation products which will prevent the actinides from being effectively back-extracted in the $0.05 \mathrm{MHNO}_{3}$ strip section. 


\section{REFERENCES}

1. A. L Olson, W. W. Schulz, L. A. Burchfield, C. D. Carlson, J. L. Swanson, and M. C. Thompson, Evaluation and Selection of Aqueous Based Technology for Partitioning Radionuclides from ICPP Calcine, WINCO-1071, February 1993.

2. E. P. Horwitz, D. G. Kalina, H. Diamond, and G. F. Vandegrift, Sol. Extr. \& Ion Exch., $\underline{3}(1 \& 2)$, $75,1985$.

3. E P. Horwitz, M. L. Dietz, and D. E. Fisher, "Extraction of Strontium from Nitric Acid Solutions Using Dicyclohexano-18-Crown-6 and its Derivatives," Sol. Extr. \& Ion Exch., $\underline{8}(4 \& 5), 557-572$, 1990.

4. E. P. Horwitz, M. L. Dietz, and D. E. Fisher, "SREX: A New Process for the Extraction and Recovery of Strontium from Acidic Nuclear Waste Streams," Sol. Extr. \& Ion Exch., 9(1), 1-25, 1991.

5. E. P. Horwitz, M. L. Dietz, and D. E. Fisher, "Extraction of Strontium from Acidic Nitrate Media using a Modified PUREX Solvent," Sol. Extr. \& Ion Exch., 13(1), 1-17, 1995.

6. D. J. Wood, J. D. Law, P. A. Tullock, T. G. Garn, R. D. Tillotson, K. N. Brewer, and T. A. Todd, Development of the SREX Process for the Treatment of ICPP Liquid Wastes, INEEL/EXT-9700831 , September 1997.

7. D. J. Wood and J. D. Law, "Evaluation of the SREX Solvent Extraction Process for the Removal of ${ }^{90} \mathrm{Sr}$ and Hazardous Metals from Acidic Nuclear Waste Solutions Containing High Concentrations of Interfering Alkali Metal Ions," Sep. Sci. \& Tech., 32(1-4), 241-253, 1997.

8. J. D. Law, D. J. Wood, and R. S. Herbst, SREX Flowsheet Development for the Separation of Strontium from ICPP Sodium-Bearing Waste Using Centrifugal Contactors, INEL-95/0314, September 1995.

9. J. D. Law and D. J. Wood, Development and Testing of a SREX Flowsheet for the Partitioning of Strontium and Lead from Simulated ICPP Sodium-Bearing Waste, INEL-96/0437, November 1996.

10. G. V. Vandegrift, et. al., "Development and Demonstration of the TRUEX Solvent Extraction Process," Proceedings of Waste Management '93, Tucson, Az, 1993, p. 1045.

11 J. D. Law, K. N. Brewer, R. S. Herbst, and T. A. Todd, Demonstration of the TRUEX Process for Partitioning of Actinides from Actual ICPP Tank Waste Using Centrifugal Contactors in a Shielded Cell Facility, INEL-96/0353, September 1996. 


\section{APPENDIX A \\ EXPERIMENTAL DATA}

A-1 


\begin{tabular}{|c|c|c|c|c|c|c|c|c|}
\hline & Sample & & & & & Analyses - Analytica & al Log 9612028 & \\
\hline Description & Label & Sr-85 (dps/mL) & $\mathrm{Pb}(\mathrm{ppm})$ & $H+(M)$ & $\mathrm{Na}(\mathrm{ppm})$ & $\mathrm{K}(\mathrm{ppm})$ & $\mathrm{Hg}(\mathrm{ppm})$ & \\
\hline \multirow[t]{2}{*}{ FEED Sample } & simulant & $1.98 \mathrm{E}+03$ & \begin{tabular}{|l|}
$3.05 E+02$ \\
\end{tabular} & & $1.58 \mathrm{E}+04$ & $3.38 E+03$ & $2.57 \mathrm{E}+02$ & \\
\hline & $1 \mathrm{aq}-30$ & $<0.38$ & & & & & & \\
\hline \multirow[t]{11}{*}{ Approach to steady-state } & $1 \mathrm{aq}-60$ & $<0.38$ & & & & & & \\
\hline & $1 \mathrm{aq}-90$ & $<0.38$ & & & & & & \\
\hline & $1 \mathrm{aq}-120$ & $<0.37$ & & & & & & \\
\hline & 1 aq-150 & & & & & & & \\
\hline & & & & & & & & \\
\hline & $13 a q-30$ & $7.35 E+02$ & & & & & & \\
\hline & $13 a q-60$ & $7.27 \mathrm{E}+02$ & & & & & & \\
\hline & $13 a q-90$ & $7.16 \mathrm{E}+02$ & & & & & & \\
\hline & $13 a q-120$ & $6.61 \mathrm{E}+02$ & & & & & & \\
\hline & $13 \mathrm{aq}-150$ & & & & & & & \\
\hline & & & & \multicolumn{2}{|c|}{ Analytical Log \#96-120210 } & & & \\
\hline Product samples & 1aq-Prod & $<5.37 E-01$ & $<7.88 \mathrm{E}-02$ & & 11582.00 & $1.60 E+03$ & $1.82 \mathrm{E}-02$ & \\
\hline taken just prior to & 13aq-Prod & $7.20 \mathrm{E}+02$ & $9.44 \mathrm{E}+00$ & & $3.70 \mathrm{E}+00$ & $5.00 \mathrm{E}+02$ & 4.73E-01 & \\
\hline shutdown & 17aq-Prod & $<5.07 \mathrm{E}-01$ & $2.10 \mathrm{E}+02$ & & 0.034 & 0.858 & $1.99 E+01$ & \\
\hline & 21aq-Prod & $<5.52 \mathrm{E}-01$ & $<7.88 \mathrm{E}-02$ & & 0.092 & $<0.03$ & 0.0404 & \\
\hline & 240r-Prod & $<5.25 \mathrm{E}-01$ & $<7.88 \mathrm{E}-02$ & & $5.20 \mathrm{E}-02$ & 0.028 & $2.14 \mathrm{E}+02$ & \\
\hline
\end{tabular}

Table A-1. Approach to steady state and steady state sample results for flowsheet testing with spiked SBW simulant. 


\begin{tabular}{|c|c|c|c|c|c|c|}
\hline Sample & & & & & Analyses - Analytica & Log \#96-120211 \\
\hline Label & $\mathrm{Sr}-85$ (dps $/ \mathrm{mL})$ & $\mathrm{Pb}(\mathrm{ppm})$ & $\mathrm{H}+(\mathrm{M})$ & $\mathrm{Na}(\mathrm{ppm})$ & $\mathrm{K}(\mathrm{ppm})$ & $\mathrm{Hg}(\mathrm{ppm})$ \\
\hline 1or & $<0.40$ & & & & & \\
\hline 1aq & $<0.37$ & $<0.37$ & $1.84 \mathrm{E}+00$ & & & \\
\hline 3or & $<0.31$ & & $1.30 E+00$ & & & \\
\hline $3 a q$ & $<0.33$ & $<0.48$ & $1.99 \mathrm{E}+00$ & & & \\
\hline 5 or & 1.46 & & $1.27 E+00$ & & & \\
\hline $5 \mathrm{aq}$ & $<0.36$ & $<0.37$ & $1.96 \mathrm{E}+00$ & & & \\
\hline 8 or & $7.39 \mathrm{E}+01$ & & $1.16 \mathrm{E}+00$ & & & \\
\hline $8 a q$ & 9.38 & $<0.48$ & $1.96 E+00$ & & & \\
\hline 10or & $1.14 E+03$ & & $1.28 \mathrm{E}+00$ & & & \\
\hline 10aq. & 141 & $<0.48$ & $2.04 E+00$ & & & \\
\hline 11 or & $1.32 E+03$ & & $1.08 \mathrm{E}+00$ & & & \\
\hline $11 a q$ & 190 & $4.86 E+00$ & $2.88 \mathrm{E}+00$ & & 1545.5 & \\
\hline 12or & $1.36 \mathrm{E}+03$ & & $9.87 \mathrm{E}-01$ & & & \\
\hline $12 \mathrm{aq}$ & 225 & $5.59 \mathrm{E}+00$ & $2.50 \mathrm{E}+00$ & & 957.7 & \\
\hline 13or & $6.13 E+02$ & & 2.96E-01 & & & \\
\hline $13 a q$ & 598 & & $7.20 \mathrm{E}-01$ & & & \\
\hline $150 r$ & $<0.32$ & & & & & \\
\hline $15 a q$ & $5.95 \mathrm{E}+00$ & $2.70 E+02$ & $1.22 \mathrm{E}-01$ & & & \\
\hline 17or & $<0.30$ & & & & & \\
\hline $17 a q$ & $<4.38 \mathrm{E}-01$ & $1.94 E+03$ & $1.39 \mathrm{E}-01$ & & & \\
\hline $190 \mathrm{r}$ & $<0.31$ & & & & & \\
\hline $19 a q$ & $<0.44$ & $9.50 \mathrm{E}-01$ & 1.33E-01 & & & \\
\hline
\end{tabular}

Table A-2. Stage samples for flowsheet testing with spiked SBW simulant. 


\begin{tabular}{|c|c|c|c|c|c|c|c|c|}
\hline & Sample & & & & & \multicolumn{3}{|c|}{ Analyses - Analytical Log $9702173,9702133,9702126$} \\
\hline Description & Label & Sr-90 & $\mathrm{Pb}$ & $\mathrm{H}+$ & $\mathrm{Na}$ & $\mathrm{K}$ & $\mathrm{Hg}$ & Talpha \\
\hline \multirow[t]{3}{*}{ FEED Sample } & feed & $\mathrm{dps} / \mathrm{mL}$ & $\mathrm{ppm}$ & Molar & $\mathrm{ppm}$ & ppm & $\mathrm{ppm}$ & $\mathrm{dps} / \mathrm{mL}$ \\
\hline & & $7.38 \mathrm{E}+06$ & 242.4 & 1.77 & $1.57 \mathrm{E}+04$ & 3690 & 469 & $2.32 E+04$ \\
\hline & $1 \mathrm{aq}-30$ & $5.77 \mathrm{E}+03$ & & & & & & \\
\hline \multirow[t]{11}{*}{ Approach to steady-state } & $1 \mathrm{aq}-60$ & $4.41 \mathrm{E}+03$ & & & & & & \\
\hline & $1 \mathrm{aq}-90$ & 316 & & & & & & \\
\hline & $1 \mathrm{aq}-120$ & 326 & & & & & & \\
\hline & & & & & & & & \\
\hline & & & & & & & & \\
\hline & $13 a q-30$ & $3.11 E+06$ & & & & & & \\
\hline & $13 a q-60$ & $3.22 E+06$ & & & & & & \\
\hline & $13 a q-90$ & $3.04 E+06$ & & & & & & \\
\hline & 13 aq-120 & $3.06 \mathrm{E}+06$ & & & & & & \\
\hline & & & & & & & & \\
\hline & & & & Analyses - Analytical & I Log 9702173,97021 & 133,9702126 & & \\
\hline Product samples & 1aq-Prod & $1.42 \mathrm{E}+03$ & $<10.80$ & $1.98 E+00$ & 10900.00 & $1.88 \mathrm{E}+03$ & $<3.78 E+01$ & $1.05 E+03$ \\
\hline taken just prior to & 13aq-Prod & 3.10E+06 & $<10.80$ & 5.10E-01 & $<1.20$ & $5.65 \mathrm{E}+02$ & $<3.78 E+01$ & $4.94 \mathrm{E}+02$ \\
\hline shutdown & 17aq-Prod & $4.35 \mathrm{E}+02$ & 166.30 & 0.104 & 20.7 & 15.9 & $<3.78 \mathrm{E}+01$ & $1.53 E+04$ \\
\hline & 21aq-Prod & $5.80 \mathrm{E}+01$ & $<5.40$ & 1.082 & 55.2 & $<13.50$ & $<3.78 E+01$ & $8.29 E+00$ \\
\hline & 24or-Prod & $4.60 E+00$ & $<0.27$ & & $4.49 \mathrm{E}+00$ & 0.81 & & $1.38 E+01$ \\
\hline
\end{tabular}

Table A-3. Approach to steady state and steady state sample results for flowsheet testing with WM-183 waste. 


\begin{tabular}{|c|c|c|c|c|c|c|c|c|}
\hline \multirow[b]{2}{*}{ Description } & \multirow{2}{*}{$\frac{\text { Sample }}{\text { Label }}$} & \multirow[b]{2}{*}{$\mathrm{Sr}-90(\mathrm{dps} / \mathrm{mL})$} & \multirow[b]{2}{*}{$\mathrm{Pb}(\mathrm{ppm})$} & \multirow[b]{2}{*}{$H+(M)$} & \multirow[b]{2}{*}{$\mathrm{Na}(\mathrm{ppm})$} & \multicolumn{3}{|c|}{ Analyses - Analytical Log 9702173, 9702133, 9702126} \\
\hline & & & & & & $\mathrm{K}(\mathrm{ppm})$ & $\mathrm{Hg}(\mathrm{ppm})$ & alpha (dps/mL) \\
\hline Extraction & 1or & & & & & & & \\
\hline & $1 \mathrm{aq}$ & $2.82 E+02$ & $<5.40 E+00$ & $1.97 E+00$ & 11200 & 1810 & $<3.78 \mathrm{E}+01$ & $8.59 \mathrm{E}+02$ \\
\hline & $30 \mathrm{r}$ & & & & & & & \\
\hline & $3 a q$ & $3.11 \mathrm{E}+02$ & $<5.40 \mathrm{E}+00$ & $2.16 E+00$ & 12900 & 3160 & $<3.78 \mathrm{E}+01$ & $1.34 E+03$ \\
\hline & 5or & $7.97 E+03$ & 7.98 & & 1060 & 2120 & & $2.64 E+02$ \\
\hline & $5 \mathrm{aq}$ & $1.31 E+03$ & $<5.40 \mathrm{E}+00$ & $2.15 E+00$ & 11600 & 3070 & $<3.78 \mathrm{E}+01$ & $1.24 \mathrm{E}+03$ \\
\hline & 6or & $2.88 \mathrm{E}+04$ & $<6.80$ & & 1250 & 2530 & & 346.3 \\
\hline & 6aq & $6.00 E+03$ & & & & & & \\
\hline & $70 \mathrm{r}$ & $1.06 \mathrm{E}+05$ & 13.7 & & 1020 & 2430 & & 265.8 \\
\hline & $7 a q$ & $1.68 \mathrm{E}+04$ & $<5.40 \mathrm{E}+00$ & 2.16 & 11700 & 3380 & $<3.78 \mathrm{E}+01$ & 1466 \\
\hline & 9or & $1.70 E+06$ & $1.71 E+01$ & & $1.07 E+03$ & $2.30 E+03$ & & $3.24 E+02$ \\
\hline & $9 a q$ & $2.60 E+05$ & & & & & & \\
\hline & $100 \mathrm{r}$ & $5.77 \mathrm{E}+06$ & $1.20 \mathrm{E}+02$ & & $1.05 E+03$ & $2.38 \mathrm{E}+03$ & & $1.17 E+04$ \\
\hline & 10aq & $9.50 E+05$ & $<5.40 \mathrm{E}+00$ & $2.16 E+00$ & $1.18 \mathrm{E}+04$ & $3.47 E+03$ & $<3.78 E+01$ & $1.38 \mathrm{E}+03$ \\
\hline Scrub & 110r & $6.90 \mathrm{E}+06$ & $2.03 E+02$ & & 441 & 1940 & & $1.71 E+04$ \\
\hline & $11 a q$ & $1.19 E+06$ & $<5.40 E+00$ & $2.91 \mathrm{E}+00$ & 1960 & 2310 & $<3.78 E+01$ & $7.33 E+02$ \\
\hline & 12or & $7.07 E+06$ & $2.05 E+02$ & & 514 & 2260 & & $1.87 \mathrm{E}+04$ \\
\hline & 12aq & $1.25 E+06$ & $<5.40 \mathrm{E}+00$ & $2.59 E+00$ & 38.9 & 1800 & $<3.78 \mathrm{E}+01$ & $3.63 E+02$ \\
\hline Strip 1 & 13or & $3.47 E+06$ & $2.68 \mathrm{E}+02$ & & & & & $1.67 \mathrm{E}+04$ \\
\hline & 13aq & $3.18 \mathrm{E}+06$ & $<5.40 \mathrm{E}+00$ & $7.28 \mathrm{E}-01$ & 2.6 & 1030 & $<3.78 \mathrm{E}+01$ & $1.05 E+03$ \\
\hline & 16or & $4.58 \mathrm{E}+01$ & $2.61 E+02$ & & $4.84 \mathrm{E}+00$ & 1.26 & & $1.34 \mathrm{E}+04$ \\
\hline & 16aq & $5.72 \mathrm{E}+02$ & $2.79 \mathrm{E}+01$ & $5.00 \mathrm{E}-02$ & $<0.60$ & 1.48 & $<3.78 \mathrm{E}+01$ & $1.85 E+03$ \\
\hline Strip 2 & 17or & $1.12 E+01$ & $<0.13$ & & $4.20 E+00$ & 1.08 & & $3.39 \mathrm{E}+02$ \\
\hline & 17aq & $1.29 E+03$ & $2.03 E+02$ & 1.07E-01 & $<0.60$ & 3.61 & $<3.78 \mathrm{E}+01$ & $1.87 \mathrm{E}+04$ \\
\hline & $200 \mathrm{r}$ & $4.09 E+01$ & $<0.13$ & & 0.69 & 0.45 & & 2.09 \\
\hline & $20 \mathrm{aq}$ & $1.22 \mathrm{E}+02$ & $<2.70$ & 0.103 & $<0.60$ & 3.03 & $<3.78 E+01$ & 65.9 \\
\hline Nitric Acid & $220 r$ & $4.67 E+01$ & $<0.13$ & & $3.68 \mathrm{E}+00$ & 1.02 & & $1.95 \mathrm{E}+01$ \\
\hline & $22 \mathrm{aq}$ & $2.25 E+02$ & $<2.70$ & $1.98 E+00$ & $<0.60$ & 3.98 & $<3.78 \mathrm{E}+01$ & $4.91 \mathrm{E}+00$ \\
\hline
\end{tabular}

Table A-4. Stage samples for flowsheet testing with WM-183 waste. 